\title{
Measurement of the Critical Distance Parameter Against Icing Conditions on a NACA 0012 Swept Wing Tip
}

Mario Vargas and Richard E. Kreeger

Glenn Research Center, Cleveland, Ohio 


\section{NASA STI Program . . . in Profile}

Since its founding, NASA has been dedicated to the advancement of aeronautics and space science. The NASA Scientific and Technical Information (STI) program plays a key part in helping NASA maintain this important role.

The NASA STI Program operates under the auspices of the Agency Chief Information Officer. It collects, organizes, provides for archiving, and disseminates NASA's STI. The NASA STI program provides access to the NASA Aeronautics and Space Database and its public interface, the NASA Technical Reports Server, thus providing one of the largest collections of aeronautical and space science STI in the world. Results are published in both non-NASA channels and by NASA in the NASA STI Report Series, which includes the following report types:

- TECHNICAL PUBLICATION. Reports of completed research or a major significant phase of research that present the results of NASA programs and include extensive data or theoretical analysis. Includes compilations of significant scientific and technical data and information deemed to be of continuing reference value. NASA counterpart of peer-reviewed formal professional papers but has less stringent limitations on manuscript length and extent of graphic presentations.

- TECHNICAL MEMORANDUM. Scientific and technical findings that are preliminary or of specialized interest, e.g., quick release reports, working papers, and bibliographies that contain minimal annotation. Does not contain extensive analysis.

- CONTRACTOR REPORT. Scientific and technical findings by NASA-sponsored contractors and grantees.
- CONFERENCE PUBLICATION. Collected papers from scientific and technical conferences, symposia, seminars, or other meetings sponsored or cosponsored by NASA.

- SPECIAL PUBLICATION. Scientific, technical, or historical information from NASA programs, projects, and missions, often concerned with subjects having substantial public interest.

- TECHNICAL TRANSLATION. Englishlanguage translations of foreign scientific and technical material pertinent to NASA's mission.

Specialized services also include creating custom thesauri, building customized databases, organizing and publishing research results.

For more information about the NASA STI program, see the following:

- Access the NASA STI program home page at http://www.sti.nasa.gov

- E-mail your question via the Internet to help@ sti.nasa.gov

- Fax your question to the NASA STI Help Desk at $443-757-5803$

- Telephone the NASA STI Help Desk at 443-757-5802

- Write to: NASA Center for AeroSpace Information (CASI) 7115 Standard Drive Hanover, MD 21076-1320 


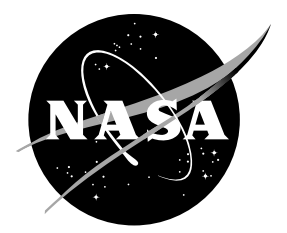

\section{Measurement of the Critical Distance Parameter Against Icing Conditions on a NACA 0012 Swept Wing Tip}

Mario Vargas and Richard E. Kreeger

Glenn Research Center, Cleveland, Ohio

Prepared for the

First Atmospheric and Space Environments Conference

sponsored by the American Institute of Aeronautics and Astronautics

San Antonio, Texas, June 22-25, 2009

National Aeronautics and

Space Administration

Glenn Research Center

Cleveland, Ohio 44135 


\section{Acknowledgments}

The present work is funded under the NASA Integrated Resilient Aircraft Controls (IRAC) Project of the Aviation Safety Program. The authors would like to thank Mr. Gene Addy and Dr. OA Guo for their support. Thanks to Mr. Ed Hermann and Mr. Mike Beyman for their help with the experiment in the Goodrich Icing Wind Tunnel (IWT). Thanks to the Icing Research Tunnel (IRT) personnel for their help with the experiment. Thanks to Mr. John Oldenburg for his help in facilitating the tunnel time exchange between the NASA IRT and the Goodrich IWT. Special thanks to Mr. Chris Lynch and Mr. Quentin Schwinn from the Imaging Technology Center for their support of the experiment and for developing and improving the measurement technique used.

Level of Review: This material has been technically reviewed by technical management.

Available from

NASA Center for Aerospace Information 7115 Standard Drive

Hanover, MD 21076-1320
National Technical Information Service 5301 Shawnee Road Alexandria, VA 22312

Available electronically at http://www.sti.nasa.gov 


\title{
Measurement of the Critical Distance Parameter Against Icing Conditions on a NACA 0012 Swept Wing Tip
}

\author{
Mario Vargas and Richard E. Kreeger \\ National Aeronautics and Space Administration \\ Glenn Research Center \\ Cleveland, Ohio 44135
}

\begin{abstract}
This work presents the results of three experiments, one conducted in the Icing Research Tunnel (IRT) at NASA Glenn Research Center and two in the Goodrich Icing Wind Tunnel (IWT). The experiments were designed to measure the critical distance parameter on a NACA 0012 Swept Wing Tip at sweep angles of $45^{\circ}, 30^{\circ}$, and $15^{\circ}$. A time sequence imaging technique (TSIT) was used to obtain real time close-up imaging data during the first $2 \mathrm{~min}$ of the ice accretion formation. The time sequence photographic data was used to measure the critical distance at each icing condition and to study how it develops in real time. The effect on the critical distance of liquid water content, drop size, total temperature, and velocity was studied. The results were interpreted using a simple energy balance on a roughness element.
\end{abstract}

\section{Nomenclature}

$\begin{array}{ll}d_{\text {crit }} & \text { Critical distance, } \mathrm{mm} \\ \Lambda & \text { Sweep angle, degrees } \\ \mathrm{V} & \text { Velocity, mph } \\ \mathrm{T}_{\text {total }} & \text { Total temperature, }{ }^{\circ} \mathrm{F} \\ \text { LWC } & \text { Cloud liquid water content, } \mathrm{g} / \mathrm{m}^{3} \\ \text { MVD } & \text { Water droplet median volume diameter, } \mu \mathrm{m} \\ \text { NACA } 0012 & \text { Wooden NACA 0012 Swept Wing Tip airfoil } \\ \text { SLD } & \text { Supercooled Large Droplets } \\ \text { IRT } & \text { Icing Research Tunnel } \\ \text { ITC } & \text { Imaging Technology Center at NASA Glenn Research Center } \\ \text { IWT } & \text { Goodrich Icing Wind Tunnel } \\ \text { TSIT } & \text { Time-Sequence Imaging Technique } \\ \beta & \text { Local collection efficiency } \\ t_{s} & \text { Surface temperature, } 32^{\circ} \mathrm{F} \text { for glaze ice } \\ \mathrm{Q}_{\text {in }} & \text { Heat flux gain for a roughness element, energy/unit area unit time } \\ \mathrm{Q}_{\text {out }} & \text { Heat flux loss for a roughness element, energy/unit area unit time }\end{array}$

\section{Introduction}

Scallop tips are complex icing structures that may be part of ice accretions on swept wings. The airfoil geometry, the sweep angle and the icing conditions determine if the scallop tips are present and the distance from the attachment line where they form. Previous studies (Refs. 1 to 7) showed that the scallop tips are made of icing feathers and their interactions. The location where the feathers begin forming with respect to the attachment line determines where the scallop tips begin and consequently the type of ice accretion that will form. The distance from the attachment line to where the feathers begin forming is called the critical distance. Measurements of the critical distance against icing conditions are needed to provide fundamental data for its modeling and prediction. Prediction of the critical distance will allow 
icing codes to anticipate the type of ice accretion that will form and specifically to anticipate if a scalloped ice accretion will be present.

Past measurements of the critical distance were made from images taken at the end of the ice accretion process. Because it was not possible to capture the details of the ice accretion when small amounts of ice were present, large ice accretion times were used. The large ice accretion times made it difficult to take accurate measurements and the technique did not allow determining how the critical distance developed in real time. Recent improvements in time sequence imaging techniques have made it possible to obtain more accurate measurements and to observe its real time development.

This report presents the results of three experiments to measure the critical distance. Two experiments were conducted at the Goodrich Icing Wind Tunnel (IWT) and one at the Icing Research Tunnel (IRT) at NASA Glenn Research Center. The objective of the experiments was to measure the effect of changes in liquid water content, drop size, total temperature and velocity on the critical distance, and to observe its real-time development on a NACA 0012 swept wing tip at $45^{\circ}, 30^{\circ}$, and $15^{\circ}$ sweep angles. A time sequence imaging technique (TSIT) developed by personnel of the Imaging Technology Center (ITC) at NASA Glenn Research Center for real time observation of the ice accretion process was extended to obtain the measurements. The test conditions were within the Appendix C envelope.

For the experiment in the IRT, time sequence close-up photographic data was obtained from a single camera positioned on the ceiling of the tunnel. For the experiment in the IWT, the smaller size of the test section permitted positioning three cameras closer to the airfoil: one on the ceiling of the tunnel and two from the side of the test section. In each experiment, additional close-up photographic data was obtained of the final ice accretion at the end of each run. The time sequence photographic data was taken at 2-sec intervals during each run for $120 \mathrm{sec}$. Before each run, a printed grid was photographed on the leading edge of the airfoil to be used as the image measurement scale. The raw data was studied frame by frame with digital imaging software and combined with the picture of the grid to obtain the measurement of the critical distance. Digital movies were also created to observe the dynamic elements in the process.

The experiments provided insights into how the critical distance develops during the first $2 \mathrm{~min}$ of the ice accretion process and allowed its measurement at different icing conditions. The database of measurements and the observations will help in the development of models that can predict the type of ice accretion that will form on swept wings.

\section{A. Icing Research Tunnel}

The IRT is a closed-loop refrigerated wind tunnel with a test section $1.8 \mathrm{~m}(6 \mathrm{ft})$ high, $2.7 \mathrm{~m}(9 \mathrm{ft})$ wide and $6.0 \mathrm{~m}(20 \mathrm{ft})$ long. The total air temperature in the test section can be varied between $-29{ }^{\circ} \mathrm{C}$ $\left(-20^{\circ} \mathrm{F}\right)$ and $1{ }^{\circ} \mathrm{C}\left(33^{\circ} \mathrm{F}\right)$ within $\pm 0.5^{\circ} \mathrm{C}\left( \pm 1{ }^{\circ} \mathrm{F}\right)$. Velocities up to $160 \mathrm{~m} / \mathrm{s}(350 \mathrm{mph})$ can be obtained with a blockage of 5 percent in the test section. A spray system allows control of the liquid water content (LWC) between 0.2 to $3.0 \mathrm{~g} / \mathrm{m}^{3}$. The spray nozzles provide droplet median volume diameters (MVD) from 14 to $50 \mu \mathrm{m}$ at Appendix C conditions and from 50 to $200 \mu \mathrm{m}$ at SLD conditions.

\section{B. Goodrich Icing Wind Tunnel}

The Goodrich Icing Wind Tunnel (IWT) is a closed-loop refrigerated wind tunnel with a test section $0.6 \mathrm{~m}(1.8 \mathrm{ft})$ wide, $1.1 \mathrm{~m}(3.7 \mathrm{ft})$ high and $1.5 \mathrm{~m}(5 \mathrm{ft})$ long. The total air temperature in the test section can be varied between $-30{ }^{\circ} \mathrm{C}\left(-22^{\circ} \mathrm{F}\right)$ and $0{ }^{\circ} \mathrm{C}\left(32^{\circ} \mathrm{F}\right)$ within $\pm 0.5^{\circ} \mathrm{C}\left( \pm 1{ }^{\circ} \mathrm{F}\right)$. Velocities from $13 \mathrm{~m} / \mathrm{s}$ (30 mph) up to $103 \mathrm{~m} / \mathrm{s}(230 \mathrm{mph}) \mathrm{can}$ be obtained. A spray system allows control of the liquid water content (LWC) between 0.1 to $3.0 \mathrm{~g} / \mathrm{m}^{3}$. The spray nozzles provide droplet median volume diameters (MVD) from 14 to $40 \mu \mathrm{m}$ at Appendix C conditions. 


\section{Model}

The model used in all the experiments was a wooden NACA 0012 swept wing tip. The airfoil has a $0.381 \mathrm{~m}$ (15 in.) chord measured normal to the leading edge, and a $0.609 \mathrm{~m}$ (24 in.) span. It is mounted in the tunnel on a stand that allows pivoting of the airfoil to sweep angles of $0^{\circ}$ to $45^{\circ}$ at $5^{\circ}$ increments. At sweep angles larger than $30^{\circ}$ a small extension was fitted at the base of the airfoil to improve the airflow. A grid was painted on the surface of the airfoil to allow identification of the flow direction on the photographic data and for placement of the printed grid used for measurement of the critical distance.

\section{Model Position in the IRT Test Section}

The model was mounted vertically in the test section at zero angle-of-attack (Fig. 1). The base of the model rested on a metallic table bolted to the tunnel floor. This is the standard position of the model in the test section where the area of observation on the leading edge is about $36 \mathrm{in}$. from the tunnel ceiling. Two sweep angles were used during the test: $45^{\circ}$ and $15^{\circ}$.

\section{E. Model Position in IWT Test Section}

The model was mounted vertically in the test section at a $30^{\circ}$ sweep angle and at zero angle-of-attack (Fig. 2). The base of the model was bolted to the tunnel floor. The position of the model allowed observation of the leading edge from a $65^{\circ}$ angle between the lens of the camera positioned on the ceiling and the attachment line direction on the airfoil. This angle was found to be the optimal through trial and error.

\section{F. Test Matrix-IRT}

Table 1 lists the test matrix for the IRT test. The table includes the run number and the icing conditions. The wooden NACA 0012 swept wing tip airfoil was used. The sweep angles tested were $15^{\circ}$ and $45^{\circ}$. A baseline icing condition was used: $\mathrm{V}=150 \mathrm{mph}, \mathrm{T}_{\text {total }}=25^{\circ} \mathrm{F}, \mathrm{LWC}=0.75 \mathrm{~g} / \mathrm{m}^{3}, \mathrm{MVD}=$ $20 \mu \mathrm{m}$. Starting from the baseline condition, runs were conducted to study the effect of changes in velocity, liquid water content, drop size and total temperature at each sweep angle. At $15^{\circ}$ sweep angle tunnel time limitations restricted the study of each effect to four runs but they covered the same overall range as the runs conducted at $45^{\circ}$ sweep angle.

\section{G. Test Matrix-IWT}

Tables 2 and 3 show the test conditions for the test entries in the Goodrich Icing Wind Tunnel. The table includes the run number and the icing conditions. The wooden NACA 0012 swept wing tip airfoil was used. The airfoil was set at a $30^{\circ}$ sweep angle for the entire experiment. A baseline icing condition was used: $\mathrm{V}=150 \mathrm{mph}, \mathrm{T}_{\text {total }}=25^{\circ} \mathrm{F}, \mathrm{LWC}=0.75 \mathrm{~g} / \mathrm{m}^{3}, \mathrm{MVD}=20 \mu \mathrm{m}$. The effect of changes in velocity, drop size, liquid water content and total temperature was studied.

\section{H. Test Procedure-IRT}

The TSIT system used a single camera located on the ceiling of the tunnel. Before each run, the camera focus was set on the area of observation. A grid was placed on the leading edge of the airfoil and a picture of it was taken and then removed. The TSIT system was activated at the start of each run when the tunnel was brought to the target velocity and total temperature and the tunnel spray system was started. During the run, the camera took time sequence close-up pictures at 2-sec intervals for $120 \mathrm{sec}$. A flash system was used for each picture. After the TSIT system stopped recording images, the tunnel was kept running for additional ice accretion time to obtain a well defined ice shape at the end of the run. Tunnel 
parameters were recorded using the NASA-Glenn Escort data acquisition system. Once the target ice accretion time was reached, the tunnel was brought to idle. After entering the tunnel, a measuring tape was placed around the ice shape, and close-up photographic data was taken in a predetermined sequence and location. A single cut was made at a predetermined location in the ice accretion to prepare for taking an ice shape tracing. A cardboard template was placed in the cut and a tracing of the ice shape was made. Following this, general observations on the ice accretion types and formations were recorded. The airfoil was cleaned before the next run.

\section{Test Procedure-IWT}

The TSIT system used a camera located on the ceiling of the tunnel and two cameras from the side of the test section (Fig. 3). One of the side cameras pointed perpendicularly to the leading edge of the airfoil, the other pointed at an angle. Before each run, the TSIT cameras' focus was set on the area of observation and a picture of the grid was taken. After the tunnel had reached the target velocity and total temperature, the TSIT system was activated either in synchronization with the tunnel spray or at a delayed time. During the run, the cameras took time sequence close-up pictures at 2 -sec intervals for $120 \mathrm{sec}$. After the TSIT system stopped taking images, the tunnel was kept running for additional ice accretion time to obtain a well defined ice shape at the end of the run. Tunnel parameters were recorded using the IWT data acquisition system. Once the target ice accretion time was reached the tunnel was brought to idle, a measuring tape was placed around the ice shape, and close-up photographic data was taken in a predetermined sequence and location. No ice shape tracings were taken during the IWT test. The airfoil was then cleaned before the next run.

\section{J. Measurement Technique}

Before each run, a picture of the grid was taken with the TSIT system. The grid picture provided the scale to measure the critical distance. To take the measurement, an ice accretion image was selected from the sixty taken by the TSIT during the run. The white tone from the grid image was removed using imaging processing software. The modified grid image and the ice accretion image were combined and the grid was used to measure the distance from the attachment line where the feathers begin forming if they are present. Figure 4 shows the technique.

\section{Results}

The growth of roughness elements into feathers is a glaze or rime ice freezing process depending on the local icing conditions at the element location. An energy balance can be adapted to interpret qualitatively if a change in the icing conditions will be favorable for the element to develop into a feather. In Section A, a simple energy balance is presented. It will be used in the interpretation of the data in subsequent sections.

\section{A. Simple Energy Balance to Interpret the Data}

Figure 5 shows the energy balance at a roughness element assuming glaze ice conditions. The energy balance is based on the one used in scaling (Ref. 8) and icing codes (Ref. 9). The heat gained by the surface of the element per unit area per unit time is the heat gained by the surface from the kinetic energy of water droplets striking the surface $\left(\mathrm{q}_{\mathrm{k}}\right)$, plus the heat gained by the surface due to the release of latent heat of fusion from freezing water $\left(\mathrm{q}_{\mathrm{f}}\right)$. The energy per unit area per unit time lost by the surface is the heat loss from the surface by convection $\left(\mathrm{q}_{\mathrm{c}}\right)$, plus the heat loss from the surface to raise the temperature of the impinging liquid to the freezing point $\left(\mathrm{q}_{\mathrm{w}}\right)$, plus the heat losses by evaporation $\left(\mathrm{q}_{\mathrm{e}}\right)$, sublimation $\left(\mathrm{q}_{\mathrm{s}}\right)$ and radiation $\left(\mathrm{q}_{\mathrm{r}}\right)$. Conduction heat transfer at the base of the element is assumed to be zero since ice is a 
good insulator. The total energy gained or lost by an element per unit time is the above heat fluxes times the area of the element.

For the purpose of interpreting the data, the effect of changing icing conditions was assumed to depend on only two terms in the heat balance. Glaze ice conditions were also assumed. For the heat gained, the kinetic energy of the water droplets term, $\mathrm{q}_{\mathrm{k}}$, was kept. For the heat loss, only heat loss by convection, $\mathrm{q}_{\mathrm{c}}$, was kept.

The heat gained from the kinetic energy of the water droplets is given by:

$$
\mathrm{Q}_{\text {in }}=\mathrm{q}_{\mathrm{k}} * \mathrm{~A}=\mathrm{LWC} * \mathrm{~V} * \beta, *\left(\mathrm{~V}^{2} / 2\right) * \mathrm{~A}
$$

where $\mathrm{LWC} * \mathrm{~V} * \beta$ is the incoming mass flux, $\mathrm{A}$ is the area of the element, $\mathrm{V}$ is the air velocity, $\mathrm{LWC}$ is the liquid water content of the cloud, and $\beta$ is the collection efficiency at the location of the element. The effect of changing the icing conditions will be to increase or decrease the heat gained, $Q_{\text {in }}$, depending on the effect that the condition change has on the velocity (V), the liquid water content of the cloud (LWC), or on the collection efficiency $(\beta)$.

For a given sweep angle $\Lambda$, the heat gain is given by:

$$
\mathrm{Q}_{\text {in, } \Lambda}=\mathrm{LWC} *[\mathrm{~V} * \cos (\Lambda)] * \beta_{\Lambda} *\left[(\mathrm{~V} * \cos (\Lambda))^{2} / 2\right] * \mathrm{~A}
$$

where the term $\beta_{\Lambda}$ accounts for the dependence of the local collection efficiency with the sweep angle and any shadowing of areas of the element from the incoming droplets due to the direction of the velocity.

The heat loss by convection is given by:

$$
\mathrm{Q}_{\text {out }}=\mathrm{q}_{\mathrm{c}} * \mathrm{~A}=\mathrm{h}_{\mathrm{c}, \text { avg }} *\left(\mathrm{t}_{\mathrm{s}}-\mathrm{t}_{\text {tot }}\right) * \mathrm{~A}
$$

where $h_{c, \text { avg }}$ is the average convection heat transfer coefficient over the element, $t_{s}$ is the surface temperature $\left(32^{\circ} \mathrm{F}\right.$ for glaze ice) and $t_{\text {tot }}$ is the total temperature of the air (assuming the recovery factor, $r$, to be equal to one). The average heat transfer coefficient over the roughness element, $\mathrm{h}_{\mathrm{c}, \mathrm{avg}}$, is proportional to a power of the velocity. The effect of changing icing conditions will be to increase or decrease $\mathrm{Q}_{\text {out }}$ depending on the effect that the condition change has on the total temperature of the air, $\mathrm{t}_{\mathrm{tot}}$, and the average heat transfer coefficient $h_{c, a v g}$ through any change in the local velocity of the air. The only icing cloud parameter not a part of Equations (1) and (2) is the mean drop diameter (MVD). The effect of changing the MVD in the icing conditions is felt through $\beta$. Increasing the MVD will increase $\beta$ at a given location.

For a given sweep angle $\Lambda$, the heat loss is given by:

$$
\mathrm{Q}_{\text {out }, \Lambda}=\mathrm{h}_{\mathrm{c}, \text { avg }, \Lambda} *\left(\mathrm{t}_{\mathrm{s}}-\mathrm{t}_{\mathrm{tot}}\right) * \mathrm{~A}
$$

where $\mathrm{h}_{\mathrm{c}, \mathrm{avg}, \Lambda}$ indicates the dependence of the average heat transfer coefficient with the sweep angle through the effect of the sweep angle on the local velocity. For roughness elements along the attachment line, that velocity is given by $\mathrm{V} * \sin (\Lambda)$.

In the analysis of the data, the effect of icing conditions on Equations (1) and (2) is considered. Figure 6 illustrates the effect of the heat balance in the formation of the critical distance. The drawing shows roughness elements and feathers forming on the leading edge of a swept wing. The critical distance is indicated with an arrow drawn from the attachment line to where the feathers begin forming. Feathers have developed from roughness elements where their energy balance is $\mathrm{Q}_{\text {out }}>\mathrm{Q}_{\text {in }}$. Roughness elements do not developed into feathers where the energy balance is $\mathrm{Q}_{\text {out }} \leq \mathrm{Q}_{\text {in }}$. The drawing also helps to illustrate that for the critical distance to decrease, the ice accretion has to be formed for icing conditions where the heat balance on the roughness element (or elements) to the left of the first feather is changed so that $\mathrm{Q}_{\text {out }}>$ $\mathrm{Q}_{\text {in. }}$. Correspondingly, to have an ice accretion with a larger critical distance, the heat balance for the roughness elements that formed feathers needs to be changed by the new icing conditions so that $\mathrm{Q}_{\text {out }} \leq$ $Q_{\text {in }}$. 


\section{B. Baseline Condition}

A baseline condition of $\Lambda=45^{\circ}, \mathrm{V}=150 \mathrm{mph}, \mathrm{T}_{\text {tot }}=25^{\circ} \mathrm{F}, \mathrm{LWC}=0.75 \mathrm{~g} / \mathrm{m}^{3}, \mathrm{MVD}=20 \mu \mathrm{m}$ was used as the starting point in the critical distance measurements. This baseline condition has been used in past experiments (Refs. 1 to 8). In past experiments the ice accretion at this baseline condition was observed to be a complete scallop $\left(\mathrm{d}_{\mathrm{cr}}=0\right)$. In the analysis of the data, the measured critical distances and ice accretion shapes were compared against the baseline condition and interpreted using the simple energy balance explained in Section A.

\section{Liquid Water Content (LWC) Effect}

Figure 7 shows the effect of changing the LWC for the baseline condition at $15^{\circ}$ and $45^{\circ}$ sweep angles. For $45^{\circ}$ at LWCs of 0.5 and $0.6 \mathrm{~g} / \mathrm{m}^{3}$ the critical distance is zero. As the LWC is increased, the critical distance increases monotonically. For $15^{\circ}$ sweep angle only four LWC cases were tested but they cover the same range as for $45^{\circ}$, from 0.5 to $1.25 \mathrm{~g} / \mathrm{m}^{3}$. The values of the critical distance for the $15^{\circ}$ sweep angle case are larger than for the $45^{\circ}$ case. The behavior of the critical distance with LWC is consistent with the energy balance from Equations (1) and (2). As the LWC is increased, the heat gained by the roughness elements increases while the heat loss remains the same. The increase in heat gained is due to the increase in the kinetic energy of the water droplets arriving on the element. The increase in kinetic energy is due to the increase in the mass flux. The roughness elements closer to the attachment line have higher values of the local collection efficiency and therefore they are the last to develop into feathers as the LWC is increased from $0.5 \mathrm{~g} / \mathrm{m}^{3}$.

The larger values of $\mathrm{d}_{\mathrm{cr}}$ for the $15^{\circ}$ sweep angle versus the $45^{\circ}$ can be interpreted in the context of the heat balance. An increase in the sweep angle for the same icing conditions will decrease the heat gained by the roughness elements while increasing the heat lost. The heat gained by the elements decreases because the local collection efficiency decreases as the sweep angle is increased, and also because the component of the velocity perpendicular to the leading edge decreases as the cosine of the sweep angle. The heat loss will increase because the heat transfer coefficient gets larger as the sweep angle increases because of the larger local velocity.

\section{Total Temperature $\left(T_{\text {tot }}\right)$ Effect}

Figure 8 shows the effect of changing the total temperature for the baseline condition at $15^{\circ}$ and $45^{\circ}$ sweep angles. For $15^{\circ}$ at a total temperature of $28^{\circ} \mathrm{F}$ the value of the critical distance is $25 \mathrm{~mm}$. As the temperature is decreased the critical distance decreases reaching a value of about $5 \mathrm{~mm}$ at $16^{\circ} \mathrm{F}$. It remains close to $5 \mathrm{~mm}$ for lower temperatures of 14 and $12^{\circ} \mathrm{F}$. For $45^{\circ}$ sweep angle the critical distance at $28^{\circ} \mathrm{F}$ is $4.3 \mathrm{~mm}$ and lowering the temperature reduces the critical distance to a value of zero. The behavior of the critical distance with temperature can be interpreted using the heat balance from Equations (1) and (2). Lowering the total temperature increases the heat loss from the element without changing the heat gained. As the total temperature is lowered, the critical distance decreases. A similar trend is observed for the $30^{\circ}$ sweep angle case as shown in Figure 9 for 150 and $200 \mathrm{mph}$.

\section{E. Mean Value Diameter (MVD) Effect}

Figure 10 shows the effect of changing the MVD for the baseline condition at $15^{\circ}$ and $45^{\circ}$ sweep angles. For $45^{\circ}$ at a MVD of $14 \mu \mathrm{m}$ the value of the critical distance is zero. As the MVD is increased the critical distance increases monotonically reaching a value of $11.1 \mathrm{~mm}$ at an MVD of $50 \mu \mathrm{m}$. The increase in the critical distance with MVD can be interpreted with the energy balance. Increasing the MVD will decrease the critical distance because as the MVD increases, the heat gained by the element increases while the heat loss remains the same. The heat gained by the roughness element increases because the 
local collection efficiency gets larger as the MVD increases. Only four cases were tested for $15^{\circ}$ sweep angle. They ranged from 20 to $50 \mu \mathrm{m}$. The behavior of the critical distance with MVD for $15^{\circ}$ sweep angle followed the same pattern observed for the $45^{\circ}$ sweep angle, the pattern expected from the heat balance. Figure 11 shows the effect of changing the MVD at $30^{\circ}$ sweep angle. The trend is the same as for the $15^{\circ}$ and $45^{\circ}$ cases but the data shows large scattering above a MVD of $25 \mu \mathrm{m}$.

Figure 12 shows the effect of total temperature on the critical distance at MVDs of 20, 25, and $30 \mu \mathrm{m}$. In all three cases as the total temperature is lowered the critical distance decreases. At a given total temperature the valued of the critical distance increases with drop size as observed before. The decrease in the critical distance at a given MVD value is due to the increase in the heat loss as the temperature is decreased.

\section{F. Velocity Effect}

The effect of velocity on the critical distance is more complex and a pattern harder to predict. This can be observed in the energy balance. As the velocity is increased, the heat gained by the element will increase but there is also an increase in the heat lost by the element because increasing the air velocity will increase the local velocity on the element affecting the heat transfer coefficient over the roughness elements. The final effect will depend on how $\mathrm{Q}_{\text {in }}$ and $\mathrm{Q}_{\text {out }}$ are changed. From the energy balance used it is not possible to predict the direction in which the critical distance is going to move when the velocity is changed.

Figure 13 shows the effect of changing the velocity for the baseline condition at $15^{\circ}$ and $45^{\circ}$ sweep angles. For $45^{\circ}$ between 100 and $120 \mathrm{mph}$ the value of the critical distance is zero. From 130 to $200 \mathrm{mph}$ the value of the critical distance increases to about $5 \mathrm{~mm}$ and remains there. For the $15^{\circ}$ sweep angle only four cases were tested in a range of velocities from 130 to $200 \mathrm{mph}$, and the critical distance decreases as the velocity is increased. The change in the critical distance is from about 19 to $11.8 \mathrm{~mm}$. Figure 14 shows the effect of changing the velocity at $30^{\circ}$ sweep angle. The value of the critical distance remains between 4 and $10 \mathrm{~mm}$ when the velocity goes from 100 to $200 \mathrm{mph}$.

\section{G. Sweep Angle Effect}

The energy balance can be used to anticipate the effect of increasing the sweep angle. As the sweep angle is increased at a given icing condition, the heat gained by an element will decrease because the local collection efficiency and the value of the component of the velocity perpendicular to the leading edge of the airfoil will decrease. On the other hand, the heat loss will increase because the heat transfer coefficient over the roughness element will increase due to the increase in the local velocity. According to the simple heat balance used to interpret the data, the critical distance at a given icing condition should decrease as the sweep angle increases. This is observed in Figures 7, 8, 10, and 13 where the value of the critical distance for the $15^{\circ}$ sweep angle case is always larger than for $45^{\circ}$.

\section{Discussion}

The measurements of the critical distance conducted in three separate experiments provided quantitative information on how the critical distance changes with icing conditions. The critical distance was found to increase with liquid water content and drop size, and to decrease with total temperature. Increasing the sweep angle decreased the critical distance. The response of the critical distance to changes in velocity was more complex since any change in the velocity modifies at the same time the heat gain and the heat loss terms in the energy balance.

The simple energy balance from Equations (1) and (2) helped to interpret the response of the critical distance to parametric changes in the liquid water content, drop size, total temperature, velocity and sweep angle. Although only two terms in the energy balance are used, the way that the energy balance 
interprets the trends in the experimental data gives confidence in its applicability. The energy balance can be used to understand results from past experiments that could not interpreted at the time such as why the formation of scallops is so strongly influenced by the local sweep angle. In previous experiments on the formation of ice accretions on swept wing (Refs. 1 to 8) it was observed that when the airfoil was set at $15^{\circ}$ sweep angle and no scallops formed on the leading edge along the span of the airfoil at a given icing condition, the change in the local sweep angle on the end cap of the airfoil, allowed the formation (on the end cap) of well defined scallops made of feathers that had grown from roughness elements. The heat balance explains this as follows: increases in local sweep angle decrease the heat gain because of the decrease in the value of the component of the velocity perpendicular to the leading edge and the decrease in the local collection efficiency, while at the same time the heat loss is increased because of the increase in the heat transfer coefficient due to the increase in local velocity at a given location. The same reasoning explains why the critical distance decreases at a given icing condition when the airfoil sweep angle is increased.

Although a good number of measurements of the critical distance against icing conditions were obtained, additional data is needed to extend the database to a wider range of icing conditions in Appendix C and SLD conditions. The experience gained in the three experiments will help to improve the accuracy of the measurement technique. The results obtained so far indicate the need to run the TSIT system for times longer than $120 \mathrm{sec}$, up to $300 \mathrm{sec}$. In the past the TSIT system could not be operated at longer than $120 \mathrm{sec}$ at 2 frames per second. This technical limitation has been removed and in future experiments the system will be operated for longer ice accretion times.

The work presented in this paper is the first step toward the development of a database of critical distance measurements against icing conditions. It is hoped that those measurements will provide clues and direction on how to predict the critical distance for a given airfoil geometry at given icing conditions. The experimental measurements of the critical distance have indicated the usefulness of the energy balance from Equations (1) and (2). The heat balance will be used to plan additional measurements of the critical distance and to begin numerical calculations that when compared to the experimental data may provide additional guidance on how to develop a model that allows the critical distance prediction, or at least a prediction of when complex scalloped ice shapes will form.

\section{References}

1. Vargas, M., "Ice Accretion on Swept Wings at Glaze Ice Conditions," Ph.D. Thesis, Case Western Reserve University, Cleveland, Ohio, May 1998.

2. Vargas, M. and Reshotko, E., "Physical Mechanisms of Glaze Ice Scallop Formations on Swept Wings,” AIAA Paper 98-0491 and NASA/TM-1998-206616, Jan. 1998.

3. Vargas, M. and Reshotko, E., "Parametric Experimental Study of the Formation of Glaze Ice Shapes on Swept Wings," AIAA Paper 99-0094, Jan. 1999.

4. Vargas, M. and Reshotko, E., "LWC and Temperature Effects on Ice Accretion Formation on Swept Wings at Glaze Ice Conditions," AIAA Paper 2000-00483, Jan. 2000.

5. Vargas, M., Giriunas, J. and Ratvasky, T., "Ice Accretion Formations on a NACA 0012 Swept Wing Tip in Natural Icing Conditions," AIAA Paper 2002-0244, Jan. 2002.

6. Vargas, M., "Current Experimental Basis for Modeling Ice Accretions on Swept Wings," AIAA Paper 2005-5188, June 2005.

7. Vargas, M., "Swept Wing Icing Physics Studies at NASA Glenn Research Center 1990-2006," SAE Paper 2007-01-3332, September 2007.

8. Anderson, D.N., "Manual of Scaling Methods," NASA/CR-2004-212875, March 2004.

9. Wright, W.B., "Users Manual for the Improved NASA Lewis Ice Accretion Code, LEWICE 1.6," NASA CR 198355, June 1995. 
TABLE 1.-IRT TEST, WOODEN NACA 0012

\begin{tabular}{|c|c|c|c|c|c|c|c|}
\hline Run number & & $\begin{array}{c}\text { Sweep } \\
\text { angle }\end{array}$ & $\begin{array}{c}\text { Velocity, } \\
\text { mph }\end{array}$ & $\begin{array}{c}\text { Total } \\
\text { temperature, } \\
{ }^{\circ} \mathrm{F}\end{array}$ & $\begin{array}{l}\mathrm{LWC}, \\
\mathrm{g} / \mathrm{m}^{3}\end{array}$ & $\begin{array}{c}\text { MVD, } \\
\mu \mathrm{m}\end{array}$ & $\begin{array}{c}\text { Ice accretion } \\
\text { time, } \\
\text { min }\end{array}$ \\
\hline 051809.01 & Baseline & $45^{\circ}$ & 150 & 25 & 1.00 & 20 & 3.0 \\
\hline \multirow[t]{2}{*}{051809.02} & & $45^{\circ}$ & 150 & 25 & 0.75 & 20 & 3.0 \\
\hline & $\begin{array}{l}\text { Velocity } \\
\text { effect }\end{array}$ & & & & & & \\
\hline 051809.03 & & $45^{\circ}$ & 100 & 25 & 0.75 & 20 & 3.0 \\
\hline 051809.04 & & $45^{\circ}$ & 100 & 25 & 0.75 & 20 & 9.7 \\
\hline 051809.05 & & $45^{\circ}$ & 110 & 25 & 0.75 & 20 & 8.9 \\
\hline 051809.06 & & $45^{\circ}$ & 120 & 25 & 0.75 & 20 & 8.1 \\
\hline 051809.07 & & $45^{\circ}$ & 130 & 25 & 0.75 & 20 & 7.5 \\
\hline 051809.08 & & $45^{\circ}$ & 140 & 25 & 0.75 & 20 & 7.0 \\
\hline 051809.09 & & $45^{\circ}$ & 150 & 25 & 0.75 & 20 & 6.5 \\
\hline 051909.01 & & $45^{\circ}$ & 160 & 25 & 0.75 & 20 & 6.1 \\
\hline 051909.02 & & $45^{\circ}$ & 170 & 25 & 0.75 & 20 & 5.7 \\
\hline 051909.03 & & $45^{\circ}$ & 180 & 25 & 0.75 & 20 & 5.4 \\
\hline 051909.04 & & $45^{\circ}$ & 190 & 25 & 0.75 & 20 & 5.1 \\
\hline \multirow[t]{3}{*}{051909.05} & & $45^{\circ}$ & 200 & 25 & 0.75 & 20 & 4.9 \\
\hline & & & & & & & \\
\hline & LWC effect & & & & & & \\
\hline 051909.06 & & $45^{\circ}$ & 150 & 25 & 0.50 & 20 & 9.8 \\
\hline 051909.07 & & $45^{\circ}$ & 150 & 25 & 1.00 & 20 & 4.9 \\
\hline 051909.08 & & $45^{\circ}$ & 150 & 25 & 1.25 & 20 & 3.9 \\
\hline 051909.09 & & $45^{\circ}$ & 150 & 25 & 0.60 & 20 & 8.1 \\
\hline \multirow[t]{2}{*}{051909.10} & & $45^{\circ}$ & 150 & 25 & 0.70 & 20 & 7.0 \\
\hline & LWC effect & & & & & & \\
\hline 052009.01 & & $45^{\circ}$ & 150 & 25 & 0.80 & 20 & 6.1 \\
\hline 052009.02 & & $45^{\circ}$ & 150 & 25 & 0.80 & 20 & 6.1 \\
\hline 052009.03 & & $45^{\circ}$ & 150 & 25 & 0.90 & 20 & 5.4 \\
\hline 052009.04 & & $45^{\circ}$ & 150 & 25 & 1.10 & 20 & 4.4 \\
\hline \multirow[t]{2}{*}{052009.05} & & $45^{\circ}$ & 150 & 25 & 1.20 & 20 & 4.1 \\
\hline & MVD effect & & & & & & \\
\hline 052009.06 & & $45^{\circ}$ & 150 & 25 & 0.75 & 14 & 6.5 \\
\hline 052009.07 & & $45^{\circ}$ & 150 & 25 & 0.75 & 18 & 6.5 \\
\hline 052009.08 & & $45^{\circ}$ & 150 & 25 & 0.75 & 22 & 6.5 \\
\hline 052009.09 & & $45^{\circ}$ & 150 & 25 & 0.75 & 26 & 6.5 \\
\hline 052009.10 & & $45^{\circ}$ & 150 & 25 & 0.75 & 30 & 6.5 \\
\hline 052009.11 & & $45^{\circ}$ & 150 & 25 & 0.75 & 34 & 6.5 \\
\hline 052009.12 & & $45^{\circ}$ & 150 & 25 & 0.75 & 38 & 6.5 \\
\hline 052009.13 & & $45^{\circ}$ & 150 & 25 & 0.75 & 42 & 6.5 \\
\hline
\end{tabular}


TABLE 1.-Concluded.

\begin{tabular}{|c|c|c|c|c|c|c|c|}
\hline Run number & & $\begin{array}{l}\text { Sweep } \\
\text { angle }\end{array}$ & $\begin{array}{c}\text { Velocity, } \\
\text { mph }\end{array}$ & $\begin{array}{c}\text { Total } \\
\text { temperature, } \\
{ }^{\circ} \mathrm{F}\end{array}$ & $\begin{array}{l}\text { LWC, } \\
\mathrm{g} / \mathrm{m}^{3}\end{array}$ & $\begin{array}{c}\text { MVD, } \\
\mu \mathrm{m}\end{array}$ & $\begin{array}{c}\text { Ice accretion } \\
\text { time, } \\
\text { min }\end{array}$ \\
\hline & $\begin{array}{c}\text { Sweep } \\
\text { angle/temp } \\
\text { effect }\end{array}$ & & & & & & \\
\hline 052109.01 & & $45^{\circ}$ & 150.00 & 10 & 0.75 & 20.00 & 6.5 \\
\hline 052109.02 & & $45^{\circ}$ & 150.00 & 15 & 0.75 & 20.00 & 6.5 \\
\hline 052109.03 & & $45^{\circ}$ & 150.00 & 20 & 0.75 & 20.00 & 6.5 \\
\hline 052109.04 & & $45^{\circ}$ & 150.00 & 30 & 0.75 & 20.00 & 6.5 \\
\hline & Velocity effect & & & & & & \\
\hline 052109.05 & & $15^{\circ}$ & 200 & 25 & 0.75 & 20 & 2.6 \\
\hline 052109.06 & & $15^{\circ}$ & 175 & 25 & 0.75 & 20 & 3.0 \\
\hline 052109.07 & & $15^{\circ}$ & 150 & 25 & 0.75 & 20 & 3.5 \\
\hline 052109.08 & & $15^{\circ}$ & 125 & 25 & 0.75 & 20 & 4.2 \\
\hline & LWC effect & & & & & & \\
\hline 052109.09 & & $15^{\circ}$ & 150 & 25 & 0.50 & 20 & 5.2 \\
\hline 052109.10 & & $15^{\circ}$ & 150 & 25 & 0.75 & 20 & 3.5 \\
\hline 052109.11 & & $15^{\circ}$ & 150 & 25 & 1.00 & 20 & 2.6 \\
\hline 052109.12 & & $15^{\circ}$ & 150 & 25 & 1.25 & 20 & 2.1 \\
\hline & MVD effect & & & & & & \\
\hline 052209.01 & & $15^{\circ}$ & 150 & 25 & 0.75 & 20 & 3.5 \\
\hline 052209.02 & & $15^{\circ}$ & 150 & 25 & 0.75 & 20 & 3.5 \\
\hline 052209.03 & & $15^{\circ}$ & 150 & 25 & 0.75 & 30 & 3.5 \\
\hline 052209.04 & & $15^{\circ}$ & 150 & 25 & 0.75 & 40 & 3.5 \\
\hline 052209.05 & & $15^{\circ}$ & 150 & 25 & 0.75 & 50 & 3.5 \\
\hline & $\begin{array}{c}\text { Sweep } \\
\text { angle/temp } \\
\text { effect }\end{array}$ & & & & & & \\
\hline 052209.06 & & $15^{\circ}$ & 150 & 30 & 0.75 & 20 & 3.5 \\
\hline 052209.07 & & $15^{\circ}$ & 150 & 28 & 0.75 & 20 & 3.5 \\
\hline 052209.08 & & $15^{\circ}$ & 150 & 26 & 0.75 & 20 & 3.5 \\
\hline 052209.09 & & $15^{\circ}$ & 150 & 24 & 0.75 & 20 & 3.5 \\
\hline 052209.10 & & $15^{\circ}$ & 150 & 20 & 0.75 & 20 & 3.5 \\
\hline 052209.11 & & $15^{\circ}$ & 150 & 18 & 0.75 & 20 & 3.5 \\
\hline 052209.12 & & $15^{\circ}$ & 150 & 16 & 0.75 & 20 & 3.5 \\
\hline 052209.13 & & $15^{\circ}$ & 150 & 14 & 0.75 & 20 & 3.5 \\
\hline 052209.14 & & $15^{\circ}$ & 150 & 12 & 0.75 & 20 & 3.5 \\
\hline
\end{tabular}


TABLE 2.-IWT TEST, WOODEN NACA 0012

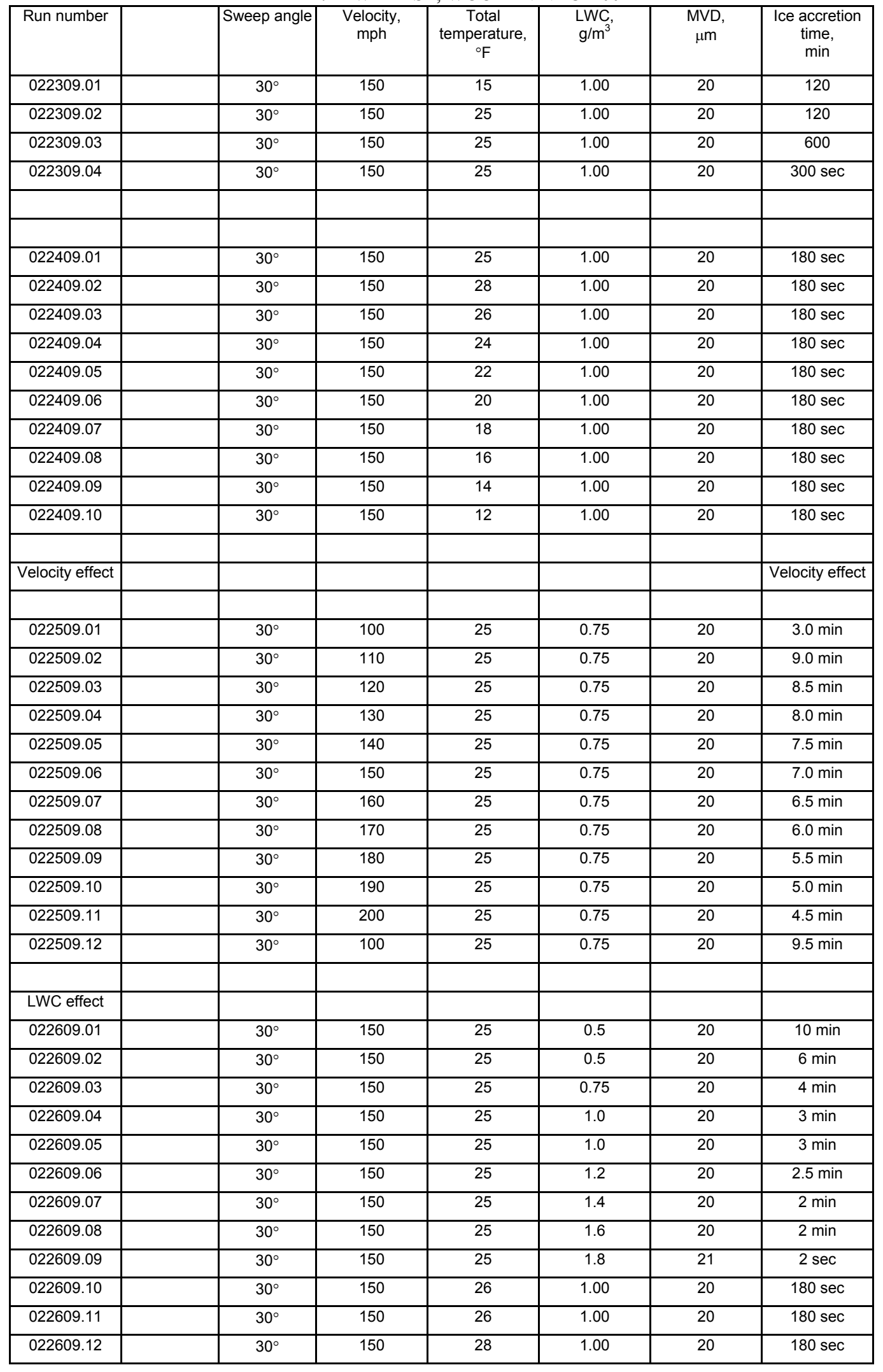


TABLE 2.-Concluded.

\begin{tabular}{|c|c|c|c|c|c|c|}
\hline Run number & Sweep angle & $\begin{array}{l}\text { Velocity, } \\
\text { mph }\end{array}$ & $\begin{array}{c}\text { Total } \\
\text { temperature, } \\
{ }^{\circ} \mathrm{F}\end{array}$ & $\begin{array}{l}\mathrm{LWCC}, \\
\mathrm{g} / \mathrm{m}^{3}\end{array}$ & $\begin{array}{c}\mathrm{MVD}, \\
\mu \mathrm{m}\end{array}$ & $\begin{array}{l}\text { Ice accretion } \\
\text { time, } \\
\text { min }\end{array}$ \\
\hline \multicolumn{7}{|l|}{ MVD effect } \\
\hline & & & & & & \\
\hline 022709.01 & $30^{\circ}$ & 150 & 25 & 0.75 & 10 & $6 \min$ \\
\hline 022709.02 & $30^{\circ}$ & 150 & 25 & 0.75 & 18 & $6 \min$ \\
\hline 022709.03 & $30^{\circ}$ & 150 & 25 & 0.75 & 20 & $6 \min$ \\
\hline 022709.04 & $30^{\circ}$ & 150 & 25 & 0.75 & 22 & $6 \min$ \\
\hline 022709.05 & $30^{\circ}$ & 150 & 25 & 0.75 & 24 & $6 \min$ \\
\hline 022709.06 & $30^{\circ}$ & 150 & 25 & 0.75 & 26 & $6 \min$ \\
\hline 022709.07 & $30^{\circ}$ & 150 & 25 & 0.75 & 28 & $6 \min$ \\
\hline 022709.08 & $30^{\circ}$ & 150 & 25 & 0.75 & 30 & $6 \min$ \\
\hline 022709.09 & $30^{\circ}$ & 150 & 25 & 0.75 & 32 & 6 min \\
\hline 022709.10 & $30^{\circ}$ & 150 & 25 & 0.75 & 34 & $6 \min$ \\
\hline 022709.11 & $30^{\circ}$ & 150 & 25 & 0.75 & 36 & $6 \min$ \\
\hline
\end{tabular}


TABLE 3.-IWT TEST, WOODEN NACA 0012

\begin{tabular}{|c|c|c|c|c|c|c|}
\hline Run number & Sweep angle & $\begin{array}{l}\text { Velocity, } \\
\text { mph }\end{array}$ & $\begin{array}{c}\text { Total } \\
\text { temperature, } \\
{ }^{\circ} \mathrm{F}\end{array}$ & $\begin{array}{l}\mathrm{LWC}, \\
\mathrm{g} / \mathrm{m}^{3}\end{array}$ & $\begin{array}{c}\mathrm{MVD}, \\
\mu \mathrm{m}\end{array}$ & $\begin{array}{c}\text { Ice accretion } \\
\text { time, } \\
\text { min }\end{array}$ \\
\hline \multicolumn{7}{|l|}{$\begin{array}{c}\text { LWC/Temp } \\
\text { effect }\end{array}$} \\
\hline 040609.01 & $30^{\circ}$ & 150 & & 050 & 20 & $100-2$ \\
\hline 年 & 0 & 0 & 20 & 0.00 & 20 & 100300 \\
\hline 040609.02 & $30^{\circ}$ & 150 & 26 & 0.50 & 20 & $180 \mathrm{sec}$ \\
\hline 040609.03 & $30^{\circ}$ & 150 & 24 & 0.50 & 20 & $180 \mathrm{sec}$ \\
\hline 040609.04 & $30^{\circ}$ & 150 & 22 & 0.50 & 20 & $180 \mathrm{sec}$ \\
\hline 040609.05 & $30^{\circ}$ & 150 & 20 & 0.50 & 20 & $360 \mathrm{sec}$ \\
\hline 040609.06 & $30^{\circ}$ & 150 & 18 & 0.50 & 20 & $360 \mathrm{sec}$ \\
\hline 040609.07 & $30^{\circ}$ & 150 & 16 & 0.50 & 20 & $360 \mathrm{sec}$ \\
\hline 040709.01 & $30^{\circ}$ & 150 & 28 & 0.75 & 20 & $240 \mathrm{sec}$ \\
\hline 040709.02 & $30^{\circ}$ & 150 & 26 & 0.75 & 20 & $240 \mathrm{sec}$ \\
\hline 040709.03 & $30^{\circ}$ & 150 & 24 & 0.75 & 20 & $240 \mathrm{sec}$ \\
\hline 040709.04 & $30^{\circ}$ & 150 & 22 & 0.75 & 20 & $240 \mathrm{sec}$ \\
\hline 040709.05 & $30^{\circ}$ & 150 & 20 & 0.75 & 20 & $240 \mathrm{sec}$ \\
\hline 040709.06 & $30^{\circ}$ & 150 & 18 & 0.75 & 20 & $240 \mathrm{sec}$ \\
\hline 040709.07 & $30^{\circ}$ & 150 & 16 & 0.75 & 20 & $240 \mathrm{sec}$ \\
\hline \multicolumn{7}{|l|}{$\begin{array}{c}\text { Velocity/Temp } \\
\text { effect }\end{array}$} \\
\hline 040709.08 & $30^{\circ}$ & 200 & 28 & 0.75 & 20 & $180 \mathrm{sec}$ \\
\hline 040709.09 & $30^{\circ}$ & 200 & 26 & 0.75 & 20 & $180 \mathrm{sec}$ \\
\hline 040709.10 & $30^{\circ}$ & 200 & 24 & 0.75 & 20 & $180 \mathrm{sec}$ \\
\hline 040709.11 & $30^{\circ}$ & 200 & 22 & 0.75 & 20 & $180 \mathrm{sec}$ \\
\hline 040709.12 & $30^{\circ}$ & 200 & 20 & 0.75 & 20 & $180 \mathrm{sec}$ \\
\hline 040709.13 & $30^{\circ}$ & 200 & 18 & 0.75 & 20 & $180 \mathrm{sec}$ \\
\hline 040709.14 & $30^{\circ}$ & 200 & 16 & 0.75 & 20 & $180 \mathrm{sec}$ \\
\hline 040709.15 & $30^{\circ}$ & 100 & 16 & 0.75 & 20 & $360 \mathrm{sec}$ \\
\hline 040709.16 & $30^{\circ}$ & 100 & 18 & 0.75 & 20 & $360 \mathrm{sec}$ \\
\hline 040809.01 & $30^{\circ}$ & 100 & 20 & 0.75 & 20 & $360 \mathrm{sec}$ \\
\hline 040809.02 & $30^{\circ}$ & 100 & 22 & 0.75 & 20 & $360 \mathrm{sec}$ \\
\hline 040809.03 & $30^{\circ}$ & 100 & 24 & 0.75 & 20 & $360 \mathrm{sec}$ \\
\hline 040809.04 & $30^{\circ}$ & 100 & 26 & 0.75 & 20 & $360 \mathrm{sec}$ \\
\hline \multicolumn{7}{|l|}{$\begin{array}{c}\text { MVD/Tem } \\
\text { effect }\end{array}$} \\
\hline & & & & & & \\
\hline 040809.05 & $30^{\circ}$ & 150 & 28 & 0.75 & 25 & $240 \mathrm{sec}$ \\
\hline 040809.06 & $30^{\circ}$ & 150 & 28 & 0.75 & 25 & $240 \mathrm{sec}$ \\
\hline 040809.07 & $30^{\circ}$ & 150 & 26 & 0.75 & 25 & $240 \mathrm{sec}$ \\
\hline 040809.08 & $30^{\circ}$ & 150 & 24 & 0.75 & 25 & $240 \mathrm{sec}$ \\
\hline 040809.09 & $30^{\circ}$ & 150 & 22 & 0.75 & 25 & $240 \mathrm{sec}$ \\
\hline 040809.10 & $30^{\circ}$ & 150 & 20 & 0.75 & 25 & $240 \mathrm{sec}$ \\
\hline
\end{tabular}


TABLE 3.-Concluded.

\begin{tabular}{|c|c|c|c|c|c|c|}
\hline Run number & Sweep angle & $\begin{array}{l}\text { Velocity, } \\
\text { mph }\end{array}$ & $\begin{array}{c}\text { Total } \\
\text { temperature, } \\
{ }^{\circ} \mathrm{F}\end{array}$ & $\begin{array}{l}\mathrm{LWC}, \\
\mathrm{g} / \mathrm{m}^{3}\end{array}$ & $\begin{array}{c}\text { MVD, } \\
\mu \mathrm{m}\end{array}$ & $\begin{array}{l}\text { Ice accretion } \\
\text { time, } \\
\text { min }\end{array}$ \\
\hline \multicolumn{7}{|l|}{$\begin{array}{c}\text { Velocity/Temp } \\
\text { effect }\end{array}$} \\
\hline 040909.01 & $30^{\circ}$ & 100 & 28 & 0.75 & 20 & $360 \mathrm{sec}$ \\
\hline \multicolumn{7}{|l|}{$\begin{array}{l}\text { MVD/Tem } \\
\text { effect }\end{array}$} \\
\hline 040909.02 & $30^{\circ}$ & 150 & 28 & 0.75 & 30 & $240 \mathrm{sec}$ \\
\hline 040909.03 & $30^{\circ}$ & 150 & 26 & 0.75 & 30 & $240 \mathrm{sec}$ \\
\hline 040909.04 & $30^{\circ}$ & 150 & 24 & 0.75 & 30 & $240 \mathrm{sec}$ \\
\hline 040909.05 & $30^{\circ}$ & 150 & 22 & 0.75 & 30 & $240 \mathrm{sec}$ \\
\hline 040909.06 & $30^{\circ}$ & 150 & 20 & 0.75 & 30 & $240 \mathrm{sec}$ \\
\hline 040909.07 & $30^{\circ}$ & 150 & 18 & 0.75 & 30 & $240 \mathrm{sec}$ \\
\hline 040809.08 & $30^{\circ}$ & 150 & 18 & 0.75 & 25 & $240 \mathrm{sec}$ \\
\hline 040909.09 & $30^{\circ}$ & 150 & 16 & 0.75 & 30 & $240 \mathrm{sec}$ \\
\hline 040809.10 & $30^{\circ}$ & 150 & 16 & 0.75 & 25 & $240 \mathrm{sec}$ \\
\hline \multicolumn{7}{|l|}{$\begin{array}{l}\text { LWC/Temp } \\
\text { effect }\end{array}$} \\
\hline 040909.11 & $30^{\circ}$ & 150 & 16 & 1.50 & 20 & $120 \mathrm{sec}$ \\
\hline 040909.12 & $30^{\circ}$ & 150 & 18 & 1.50 & 20 & $120 \mathrm{sec}$ \\
\hline 040909.13 & $30^{\circ}$ & 150 & 20 & 1.50 & 20 & $120 \mathrm{sec}$ \\
\hline 040909.14 & $30^{\circ}$ & 150 & 22 & 1.50 & 20 & $120 \mathrm{sec}$ \\
\hline 040909.15 & $30^{\circ}$ & 150 & 24 & 1.50 & 20 & $120 \mathrm{sec}$ \\
\hline 040909.16 & $30^{\circ}$ & 150 & 26 & 1.50 & 20 & $120 \mathrm{sec}$ \\
\hline 040909.17 & $30^{\circ}$ & 150 & 28 & 1.50 & 20 & $120 \mathrm{sec}$ \\
\hline
\end{tabular}




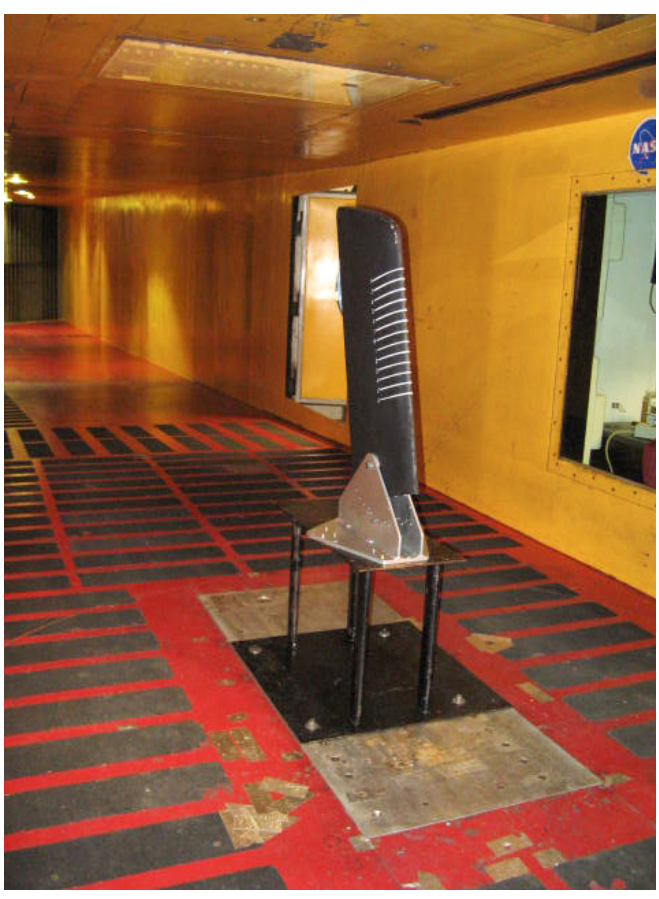

Figure 1.-Wooden NACA 0012 swept wing tip in the IRT test section.

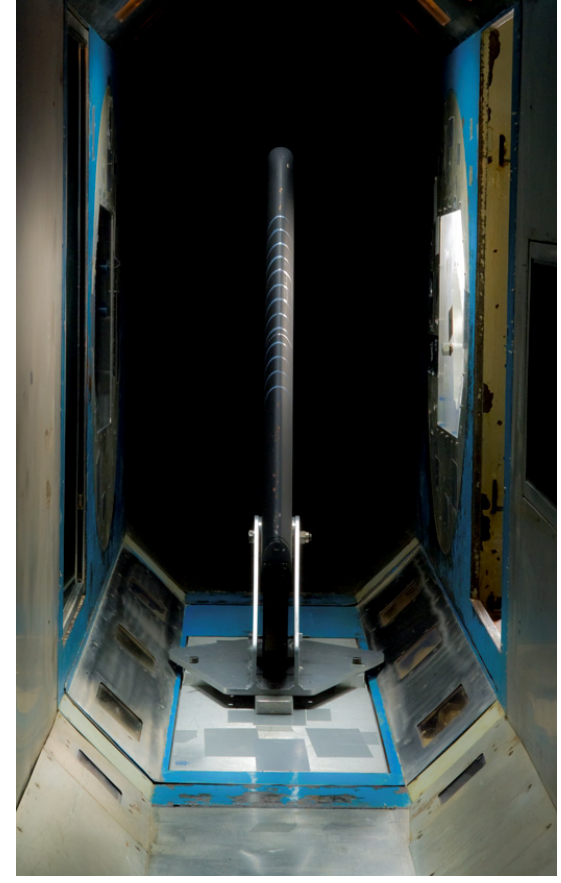

Figure 2.-Wooden NACA 0012 swept wing tip in the Goodrich Icing Wind Tunnel test section.

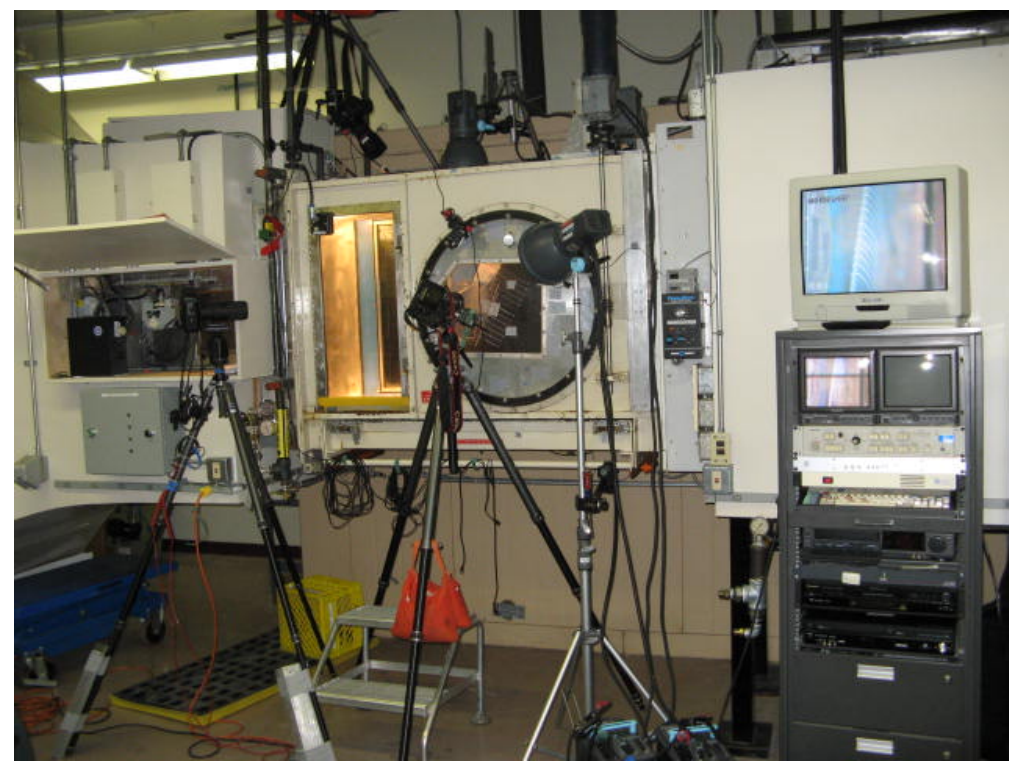

Figure 3.-Experiment set-up in the Goodrich Icing Wind Tunnel. The camera on the ceiling of the tunnel is pointing at a $65^{\circ}$ angle with respect to the leading edge of the airfoil. 

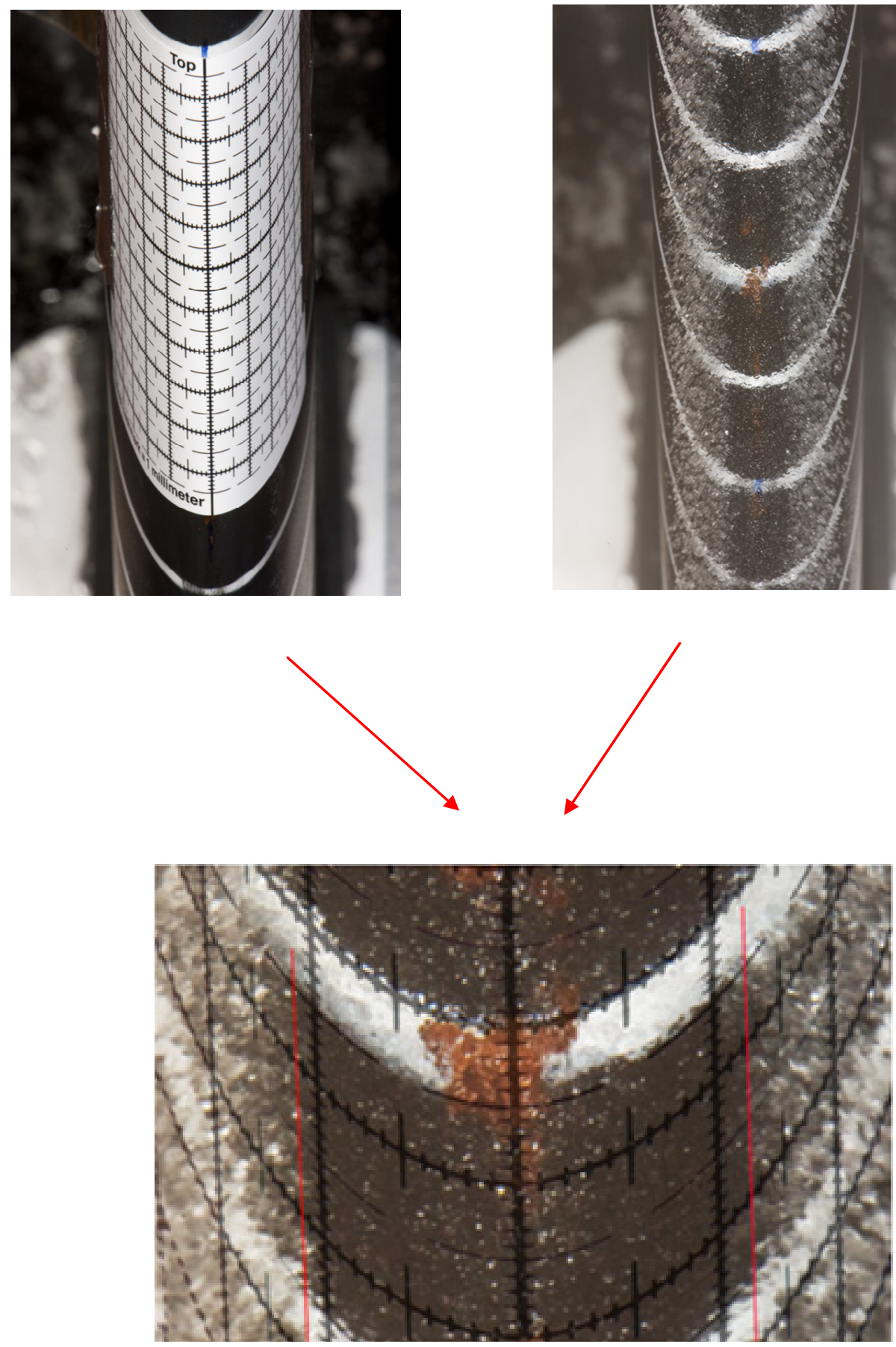

Figure 4.-Measurement technique. The picture of the grid and the image are combined to extract the measurement of the critical distance. The red lines indicate the location where the feathers begin forming. 


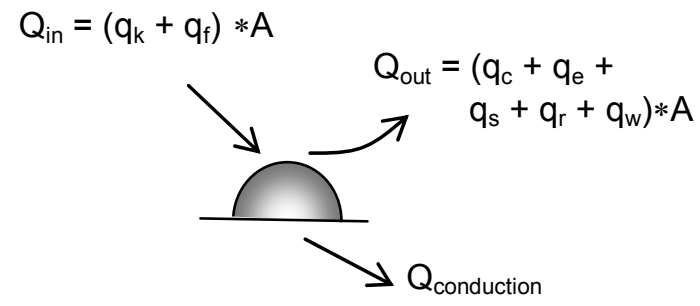

(a)

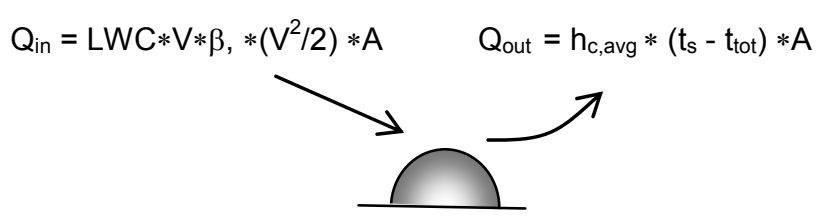

(b)

Figure 5.-(a) Energy balance on a single roughness element; (b) The approximated energy balance used to interpret the data.
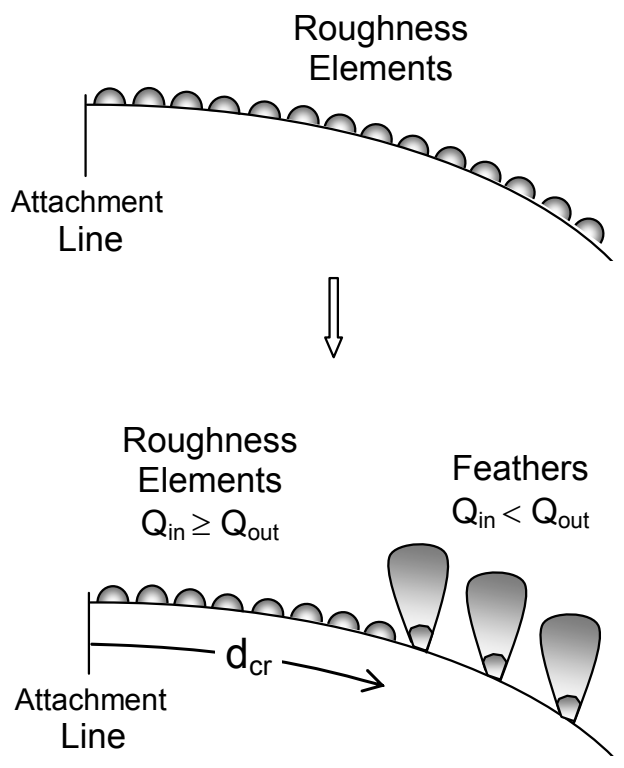

Figure 6.-Energy balance in the zone where roughness elements develop into feathers and in the zone where they do not. 


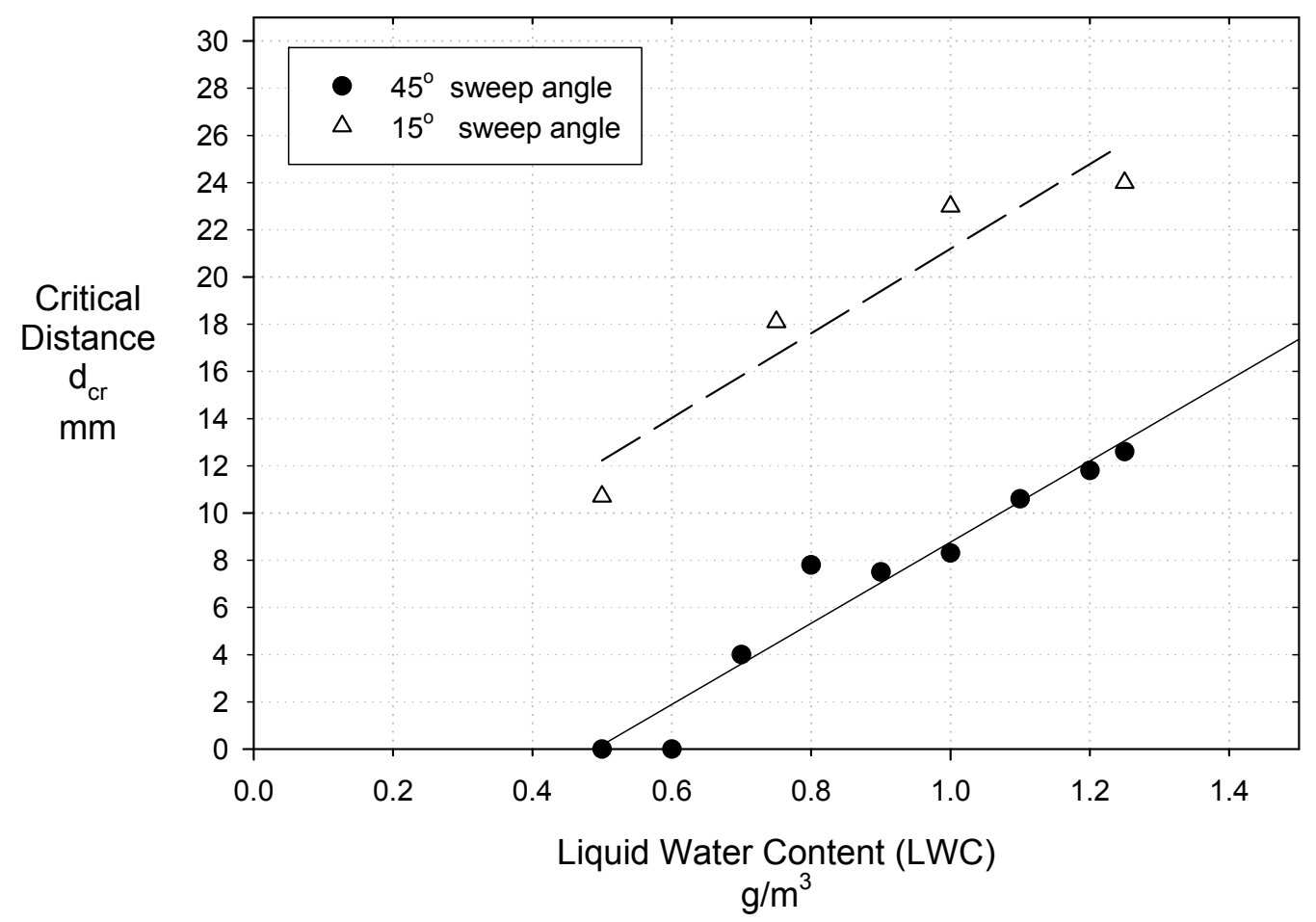

Figure 7.-Change in critical distance with liquid water content for $15^{\circ}$ and $45^{\circ}$ sweep angles, Wooden NACA 0012, V = $150 \mathrm{mph}, \mathrm{T}_{\text {total }}=25^{\circ} \mathrm{F}, \mathrm{MVD}=20 \mu \mathrm{m}$.

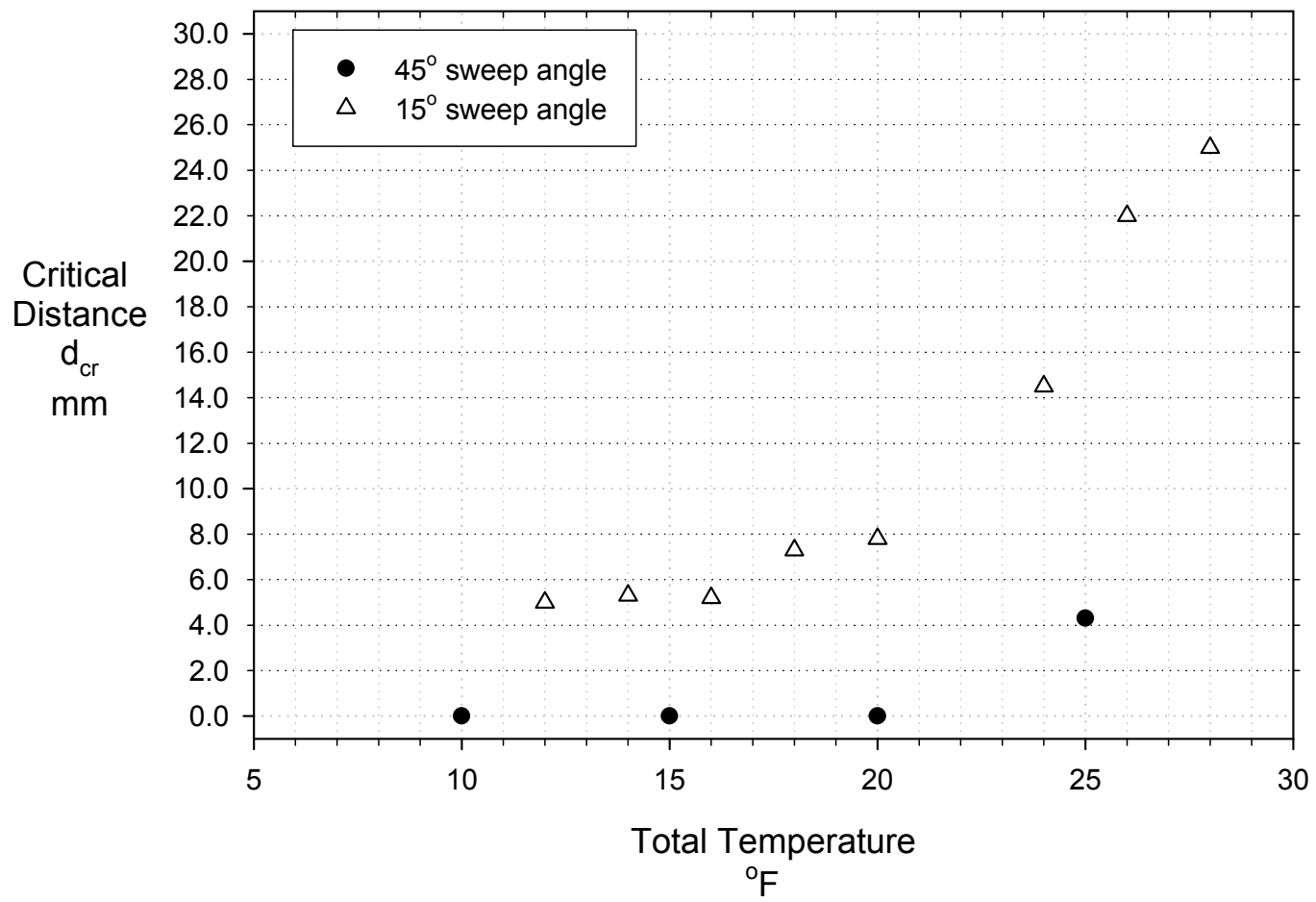

Figure 8.-Change in critical distance with total temperature for $15^{\circ}$ and $45^{\circ}$ sweep angles, Wooden NACA 0012, V = $150 \mathrm{mph}, \mathrm{LWC}=0.75 \mathrm{~g} / \mathrm{m}^{3}, \mathrm{MVD}=20 \mu \mathrm{m}$. 


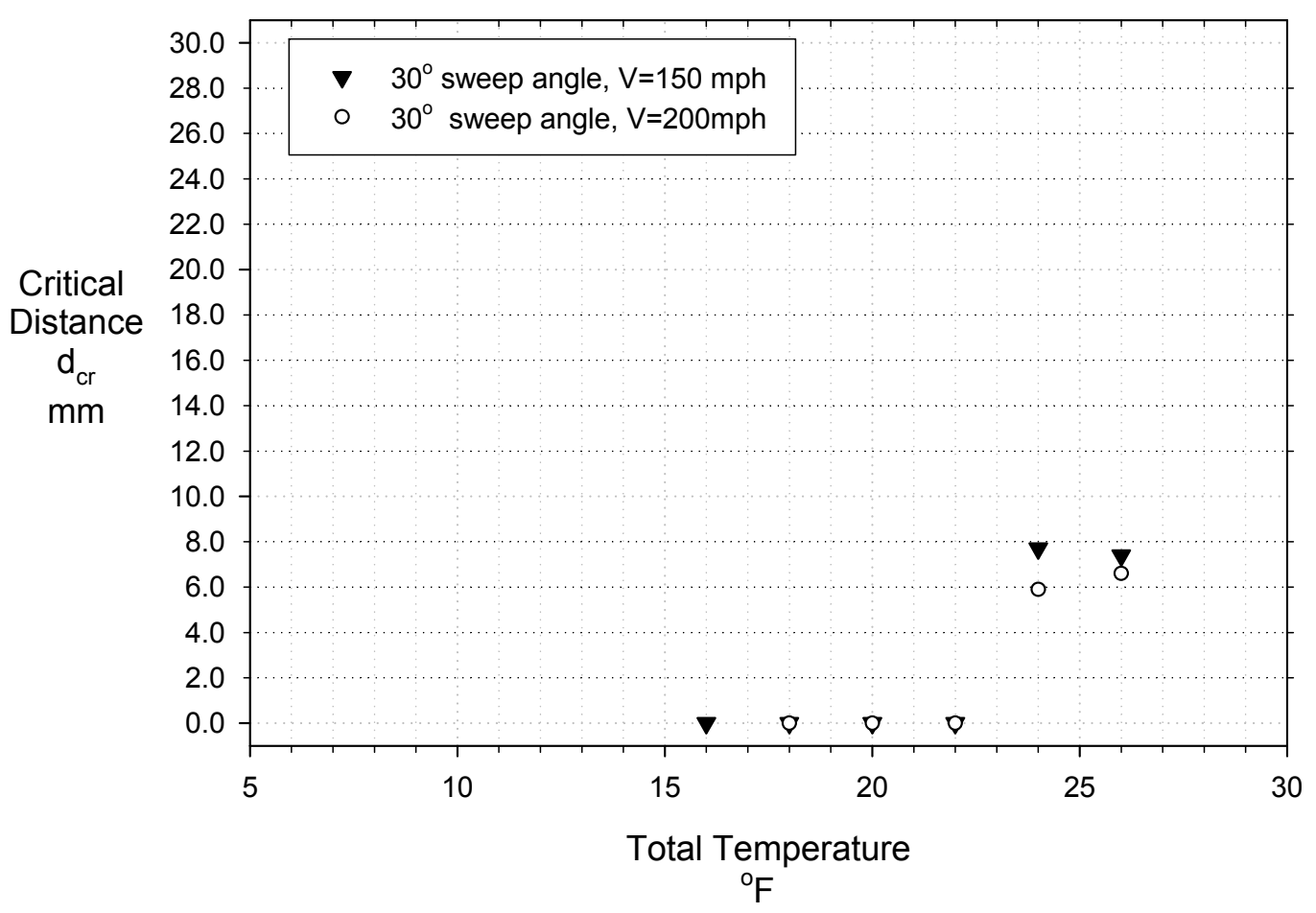

Figure 9.-Change in critical distance with total temperature for $30^{\circ}$ sweep angles at velocities of 150 and $200 \mathrm{mph}$, Wooden NACA 0012, LWC $=0.75 \mathrm{~g} / \mathrm{m}^{3}, \mathrm{MVD}=20 \mu \mathrm{m}$.

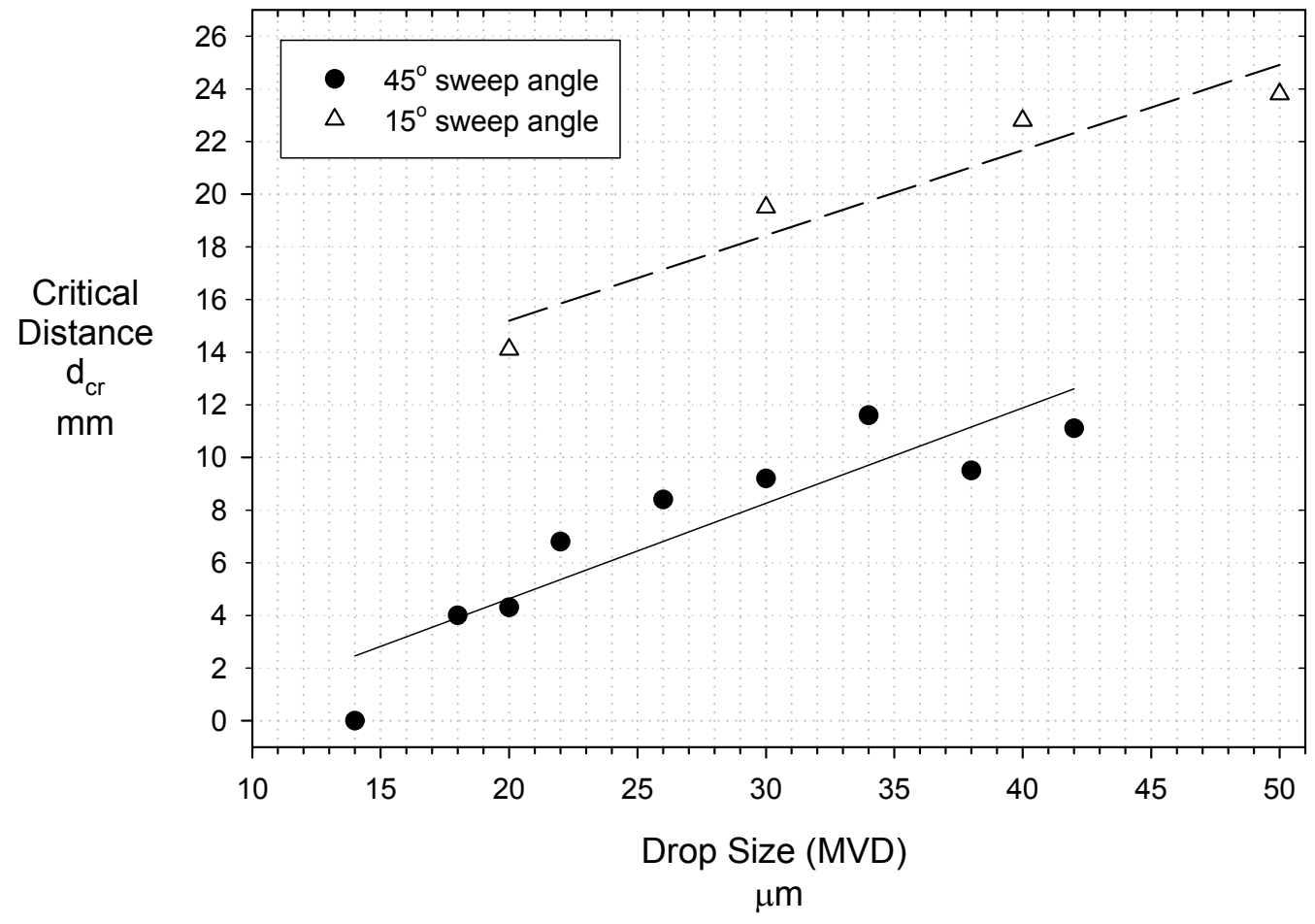

Figure 10.-Change in critical distance with drop size for $15^{\circ}$ and $45^{\circ}$ sweep angles, Wooden NACA 0012, V = $150 \mathrm{mph}, T_{\text {total }}=25^{\circ} \mathrm{F}, \mathrm{LWC}=0.75 \mathrm{~g} / \mathrm{m}^{3}$. 


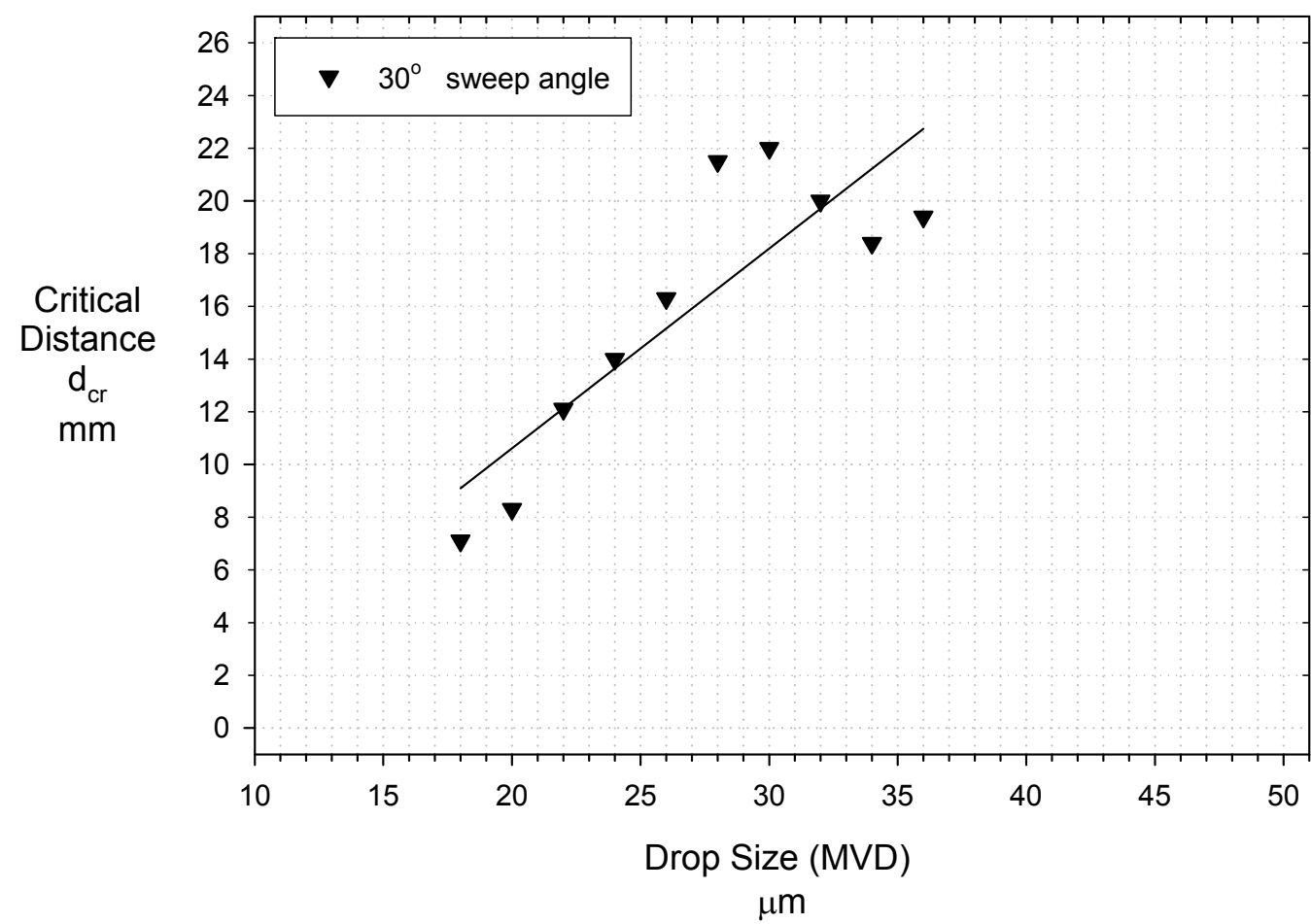

Figure 11.-Change in critical distance with drop size for $30^{\circ}$ sweep angle, Wooden NACA 0012 , $\mathrm{V}=150 \mathrm{mph}, \mathrm{T}_{\text {total }}=25^{\circ} \mathrm{F}, \mathrm{LWC}=0.75 \mathrm{~g} / \mathrm{m}^{3}$.

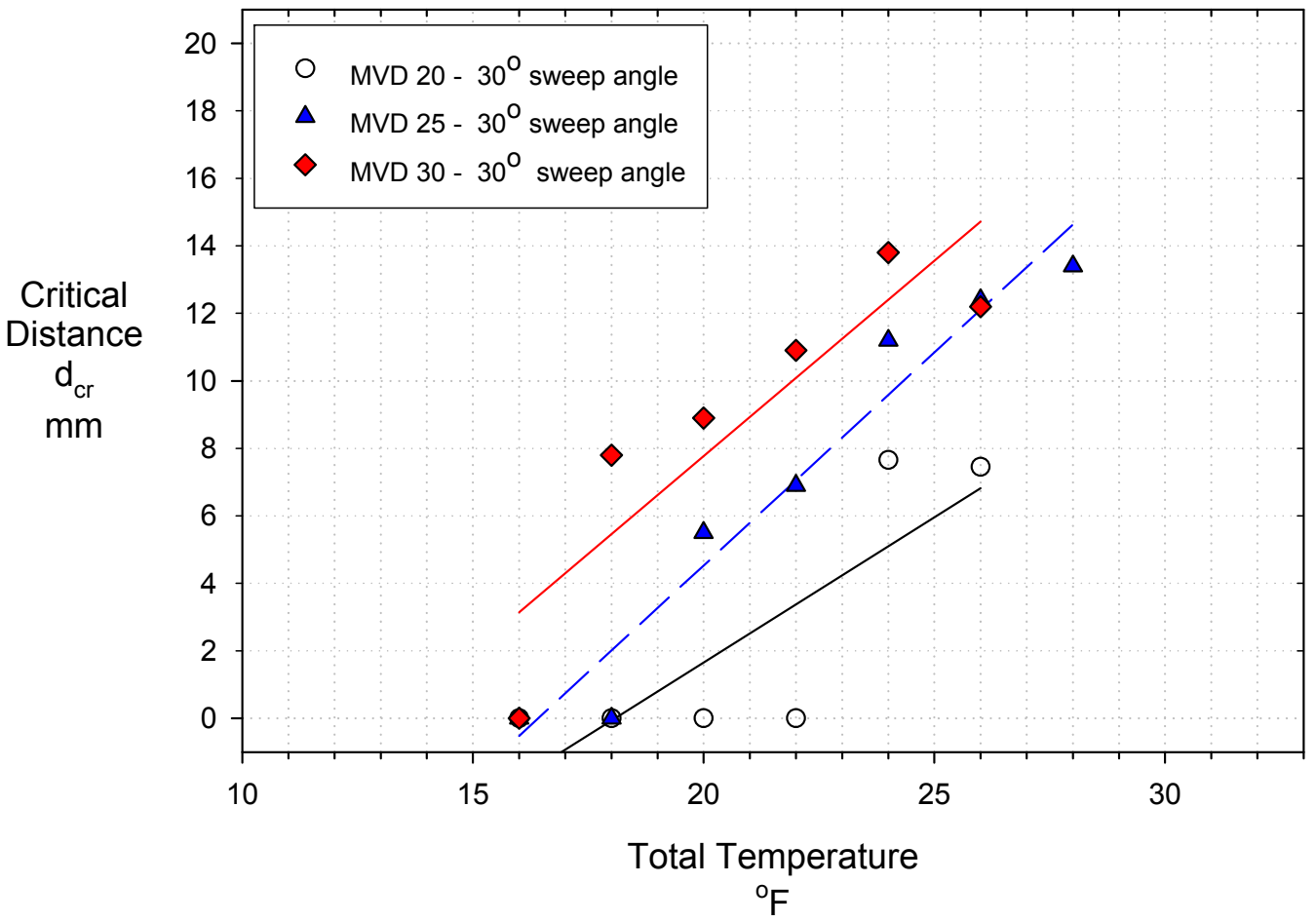

Figure 12.-Change in critical distance with total temperature for $30^{\circ}$ sweep angles at MVDs of 20,25 , and $30 \mathrm{~mm}$, Wooden NACA 0012, V $=150 \mathrm{mph}, \mathrm{LWC}=0.75 \mathrm{~g} / \mathrm{m}^{3}$. 


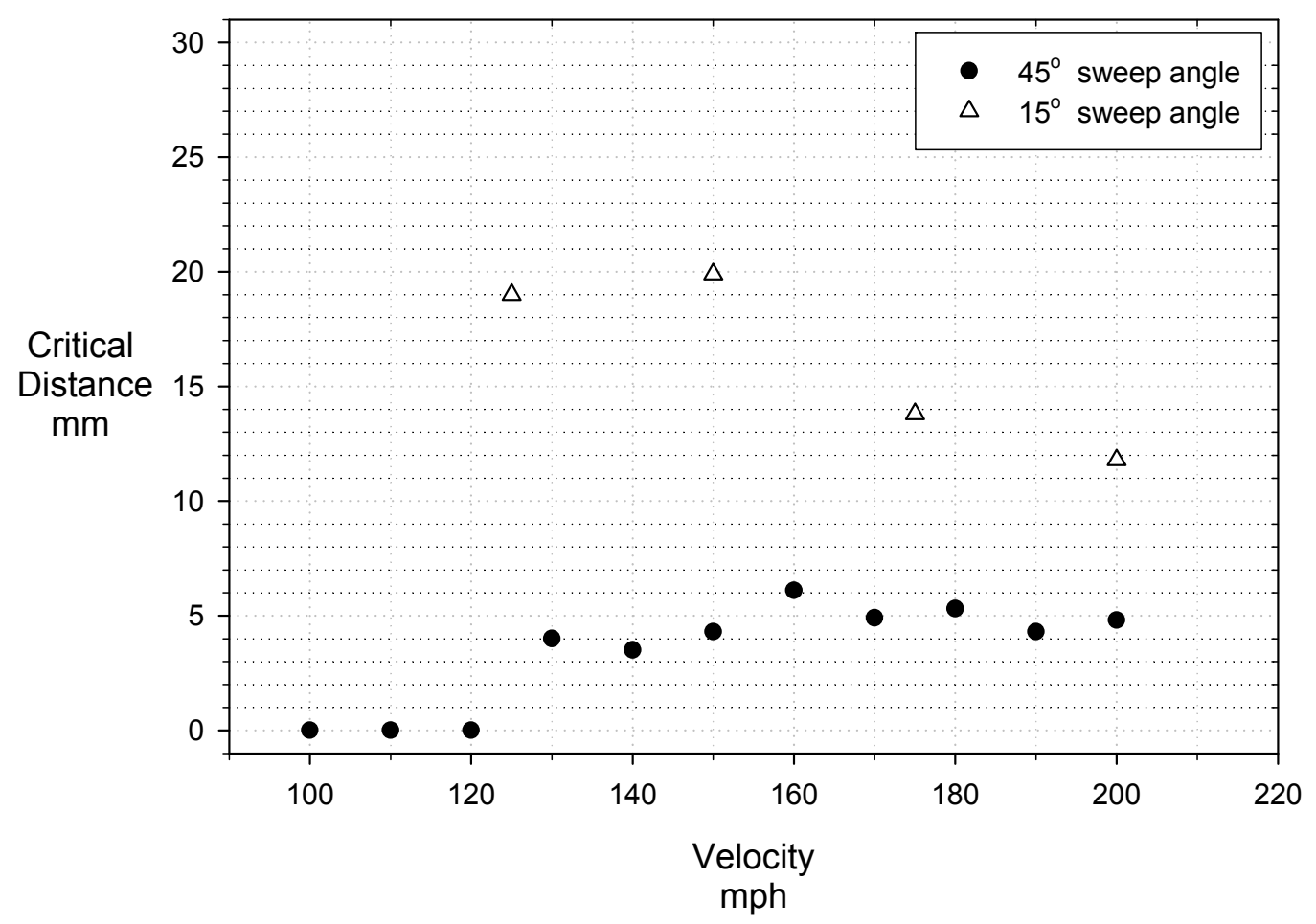

Figure 13.-Change in critical distance with velocity for $15^{\circ}$ and $45^{\circ}$ sweep angles, Wooden NACA 0012, $T_{\text {total }}=25^{\circ} \mathrm{F}, \mathrm{LWC}=0.75 \mathrm{~g} / \mathrm{m}^{3}, \mathrm{MVD}=20 \mu \mathrm{m}$.

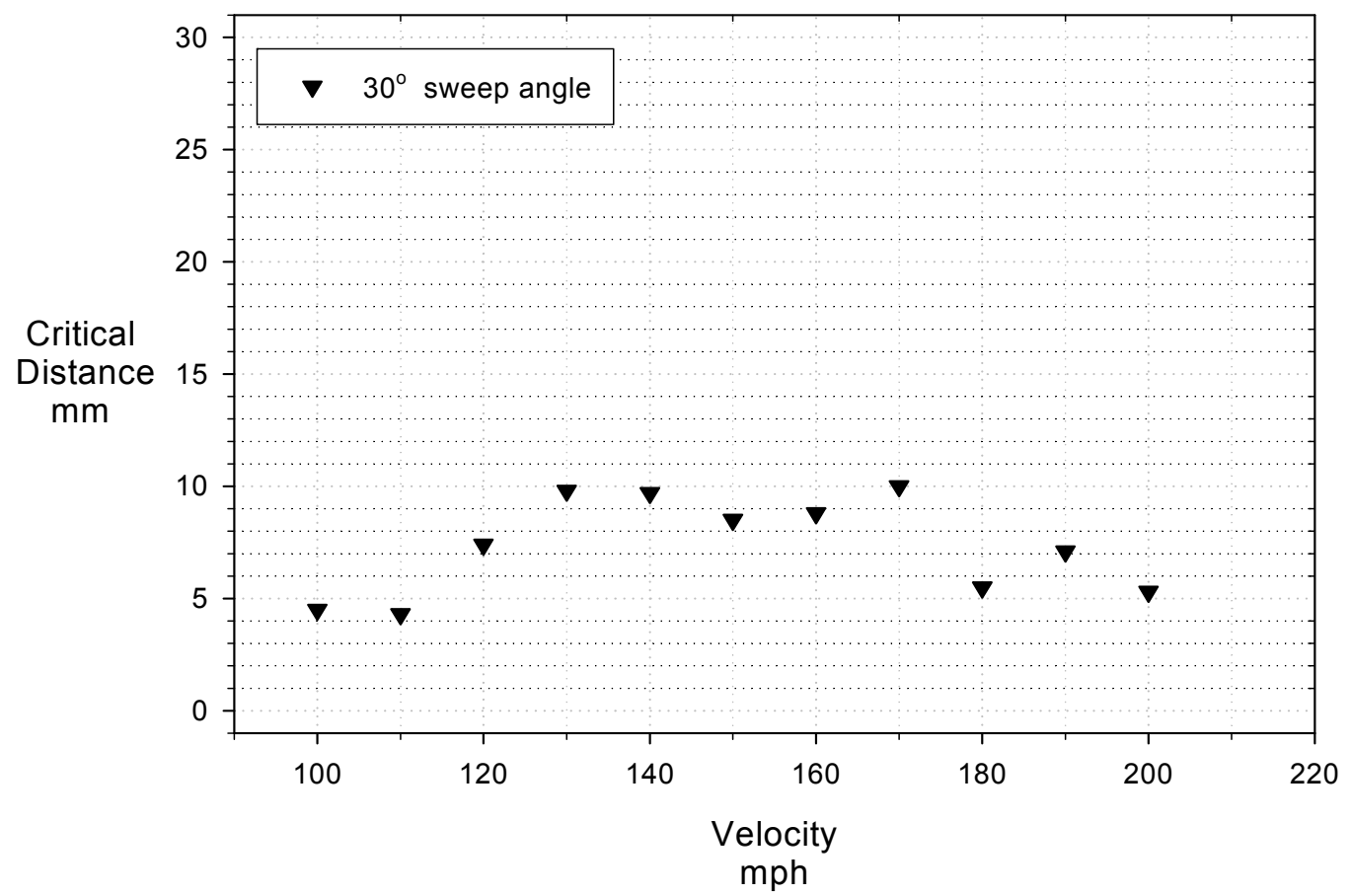

Figure 14.-Change in critical distance with velocity for $30^{\circ}$ sweep angle, Wooden NACA 0012 , $\mathrm{T}_{\text {total }}=25^{\circ} \mathrm{F}, \mathrm{LWC}=0.75 \mathrm{~g} / \mathrm{m}^{3}, \mathrm{MVD}=20 \mu \mathrm{m}$. 


\begin{tabular}{|c|c|c|c|c|c|}
\hline \multicolumn{5}{|c|}{ REPORT DOCUMENTATION PAGE } & $\begin{array}{l}\text { Form Approved } \\
\text { OMB No. 0704-0188 }\end{array}$ \\
\hline \multicolumn{6}{|c|}{ 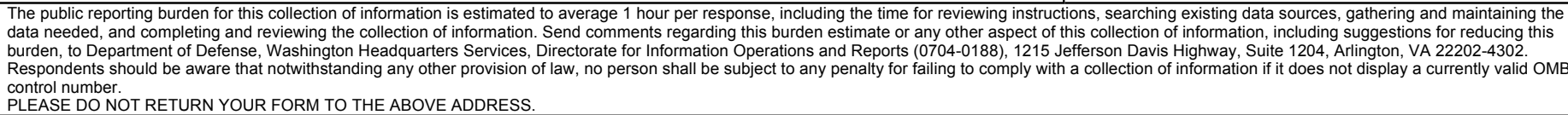 } \\
\hline \multicolumn{2}{|c|}{$\begin{array}{l}\text { 1. REPORT DATE (DD-MM-YYYY) } \\
01-02-2011\end{array}$} & \multicolumn{3}{|c|}{$\begin{array}{l}\text { 2. REPORT TYPE } \\
\text { Technical Memorandum }\end{array}$} & 3. DATES COVERED (From - To) \\
\hline \multirow{3}{*}{\multicolumn{5}{|c|}{$\begin{array}{l}\text { 4. TITLE AND SUBTITLE } \\
\text { Measurement of the Critical Distance Parameter Against Icing Conditions on a NACA 0012 } \\
\text { Swept Wing Tip }\end{array}$}} & 5a. CONTRACT NUMBER \\
\hline & & & & & 5b. GRANT NUMBER \\
\hline & & & & & 5c. PROGRAM ELEMENT NUMBER \\
\hline \multirow{3}{*}{\multicolumn{5}{|c|}{$\begin{array}{l}\text { 6. AUTHOR(S) } \\
\text { Vargas, Mario; Kreeger, Richard, E. }\end{array}$}} & 5d. PROJECT NUMBER \\
\hline & & & & & 5e. TASK NUMBER \\
\hline & & & & & $\begin{array}{l}\text { 5f. WORK UNIT NUMBER } \\
\text { WBS 457289.02.07.03.03.04 }\end{array}$ \\
\hline \multicolumn{5}{|c|}{$\begin{array}{l}\text { 7. PERFORMING ORGANIZATION NAME(S) AND ADDRESS(ES) } \\
\text { National Aeronautics and Space Administration } \\
\text { John H. Glenn Research Center at Lewis Field } \\
\text { Cleveland, Ohio 44135-3191 }\end{array}$} & $\begin{array}{l}\text { 8. PERFORMING ORGANIZATION } \\
\text { REPORT NUMBER } \\
\text { E-17571 }\end{array}$ \\
\hline \multirow{2}{*}{\multicolumn{5}{|c|}{$\begin{array}{l}\text { 9. SPONSORING/MONITORING AGENCY NAME(S) AND ADDRESS(ES) } \\
\text { National Aeronautics and Space Administration } \\
\text { Washington, DC 20546-0001 }\end{array}$}} & $\begin{array}{l}\text { 10. SPONSORING/MONITOR'S } \\
\text { ACRONYM(S) } \\
\text { NASA }\end{array}$ \\
\hline & & & & & $\begin{array}{l}\text { 11. SPONSORING/MONITORING } \\
\text { REPORT NUMBER } \\
\text { NASA/TM-2011-216966 }\end{array}$ \\
\hline \multicolumn{6}{|c|}{$\begin{array}{l}\text { 12. DISTRIBUTION/AVAILABILITY STATEMENT } \\
\text { Unclassified-Unlimited } \\
\text { Subject Categories: } 01,03,31 \text {, and } 34 \\
\text { Available electronically at http://www.sti.nasa.gov } \\
\text { This publication is available from the NASA Center for AeroSpace Information, 443-757-5802 }\end{array}$} \\
\hline \multicolumn{6}{|c|}{ 13. SUPPLEMENTARY NOTES } \\
\hline \multicolumn{6}{|c|}{$\begin{array}{l}\text { 14. ABSTRACT } \\
\text { This work presents the results of three experiments, one conducted in the Icing Research Tunnel (IRT) at NASA Glenn Research Center and } \\
\text { two in the Goodrich Icing Wind Tunnel (IWT). The experiments were designed to measure the critical distance parameter on a NACA } 0012 \\
\text { Swept Wing Tip at sweep angles of } 45^{\circ}, 30^{\circ} \text {, and } 15^{\circ} \text {. A time sequence imaging technique (TSIT) was used to obtain real time close-up } \\
\text { imaging data during the first } 2 \text { min of the ice accretion formation. The time sequence photographic data was used to measure the critical } \\
\text { distance at each icing condition and to study how it develops in real time. The effect on the critical distance of liquid water content, drop } \\
\text { size, total temperature, and velocity was studied. The results were interpreted using a simple energy balance on a roughness element. }\end{array}$} \\
\hline \multicolumn{6}{|c|}{$\begin{array}{l}\text { 15. SUBJECT TERMS } \\
\text { Ice accretion; Swept wings; Scallop formations }\end{array}$} \\
\hline \multicolumn{3}{|c|}{ 16. SECURITY CLASSIFICATION OF: } & $\begin{array}{l}\text { 17. LIMITATION OF } \\
\text { ABSTRACT }\end{array}$ & $\begin{array}{l}\text { 18. NUMBER } \\
\text { OF }\end{array}$ & $\begin{array}{l}\text { 19a. NAME OF RESPONSIBLE PERSON } \\
\text { STI Help Desk (email:help } \text { asti.nasa.gov) }\end{array}$ \\
\hline $\begin{array}{l}\text { a. REPORT } \\
\text { U }\end{array}$ & $\begin{array}{l}\text { b. ABSTRACT } \\
\mathrm{U}\end{array}$ & $\begin{array}{l}\text { c. THIS } \\
\text { PAGE } \\
\text { U }\end{array}$ & UU & $\begin{array}{l}\text { PAGES } \\
27\end{array}$ & $\begin{array}{l}\text { 19b. TELEPHONE NUMBER (include area code) } \\
443-757-5802\end{array}$ \\
\hline
\end{tabular}



